Migration and Labour Force Participation: Analysis of internal Economic Migrants in Gauteng South Africa, 2011.

By MALESELA THOKA

Mini-thesis presented in partial fulfilment of the requirements for the degree Master of Philosophy in Urban and Regional Science in the Faculty of Arts and Social Sciences at Stellenbosch

University

Supervisor: Prof Manie Geyer

March 2017 


\section{AUTHOR'S DECLARATION}

By submitting this mini-thesis electronically, I declare that the entirety of the work contained therein is my own, original work, that I am the sole author thereof (save to the extent explicitly otherwise stated), that reproduction and publication thereof by Stellenbosch University will not infringe any third party rights and that I have not previously in its entirety or in part submitted it for obtaining any qualification.

Date: March 2017

Copyright $@ 2017$ Stellenbosch University

All rights reserved 


\begin{abstract}
Historically Gauteng has always been the centre of attraction for the migrants from other parts of the country in search of economic opportunities and a better life. What has always been the question was whether Gauteng is able to economically absorb this flow mainly from rural areas into its workforce. Using census 2011 data the study investigates individual and socio-economic characteristics that are significant to migrants being employed and unemployed and whether migrants at different age groups have a better chance of being employed in the province of origin or in Gauteng.

The analysis is conducted at three levels i.e. univariate, bivariate and multivariate using statistical techniques such as frequency tables, graphs of cross-tabulations, chi-square and binary logistics regression.

The results show that selected individual and socio-economic characteristics are significant and highly associated with internal migrants being employed or unemployed in Gauteng.
\end{abstract}

\title{
Keywords and phrases:
}

Internal migration

Individual and socio-economic factors

Economic theories

Rural-urban migration

Spatial settlement

Main place 


\section{OPSOMMING}

In die soeke na ekonomiese geleenthede en ' $n$ beter lewe, was Gauteng nog altyd die midddelpunt van belangstelling vir migrante vanuit ander dele van die land. Die vraag was egter nog altyd of Gauteng in staat is om hierdie vloei van hoofsaaklik plattelandse areas in hul werkmag ekonomies kan absorbeer. Deur gebruik te maak van 2011 Sensus data doen hierdie studie ondersoek na die individuele en sosio-ekonomiese eienskappe wat beduidend is vir migrante wat indiensgeneem en werkloos is. Verder poog die ondersoek om te bepaal of migrante van verskillende ouderdom's groepe ' $n$ beter kans het om indiens geneem te word in hul provinsie van oorsprong of in Gauteng.

Hierdie analise word uitgevoer op drie vlakke nl. Eenveranderlike-, tweeveranderlikee, en multiveranderlike analises, waarin van statistiese tegnieke soos frekwensie tabelle, kruistabulering's grafieke, chi-kwadraat en binêre logistieke regressie gebruik gemaak word.

Die resultate dui aan dat geselekteerde individue en sosio-ekonomiese karaktertrekke beduidend is en hoogs geassosieer word met interne migrante wat indiensgeneem of werkloos is in Gauteng.

\section{Trefwoorde en frases:}

Interne migrasie

Individuele en ekonomieese faktore

Ekonomiese teorieë

Landelike-stedelike migrasie

Ruimtelike nedersettings

Belangrikste/ hoof plek 


\section{ACKNOWLEDGEMENTS}

My sincere appreciation thanks and goes to the following people for their assistance with my minithesis:

- Prof Geyer for his invaluable support and guidance throughout the whole process as my supervisor.

- My family for always been there for me even during tough times, when we lost our beloved father during the compilation of this work.

- Leonard Ahuejere, Michael Segage and Jonas Ngobeni for always motivating and encouraging me during the process and even editing my work.

- Stats SA for providing me with this wonderful eye-opening opportunity to explore and learn. 


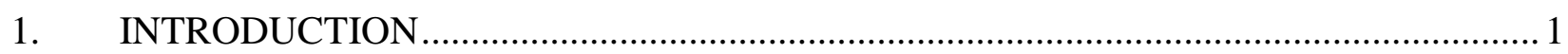

1.1. Background and rationale..........................................................................................

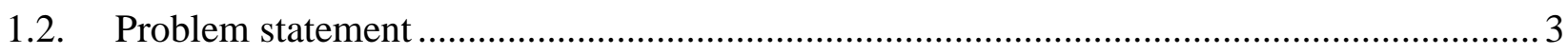

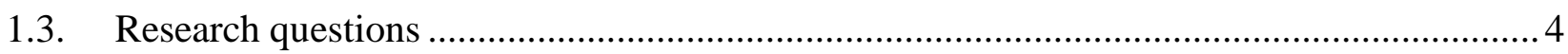

1.4. Aims and Objectives ......................................................................................... 4

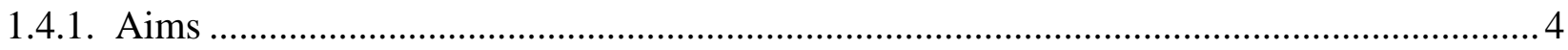

1.4.2. General objectives ..................................................................................................... 4

1.4.3. Specific objectives.............................................................................................. 4

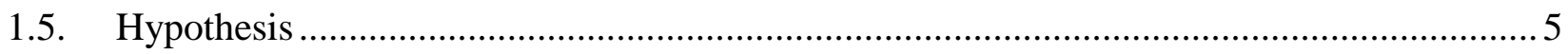

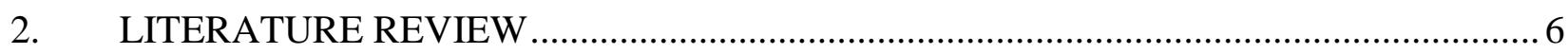

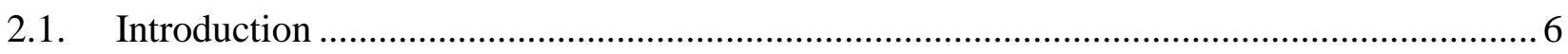

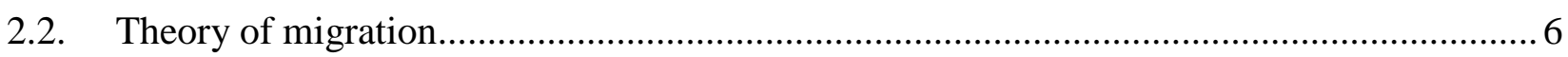

2.3. Macro and micro perspective of neoclassical theory ........................................................... 7

2.3.1. Criticism of the neoclassical theory ………………….................................................... 11

2.3.2. Application of neoclassical theory ………………………............................................. 12

2.4. The New Economics of Migration ............................................................................. 14

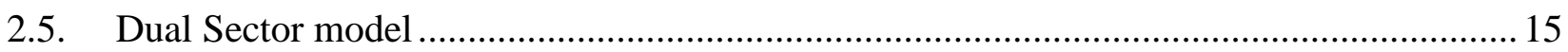

2.6. The South African context of economic theory of migration ................................................16

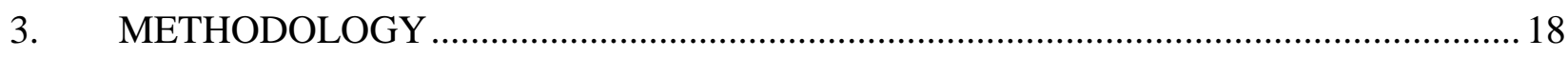

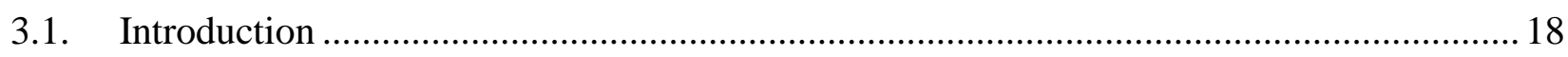

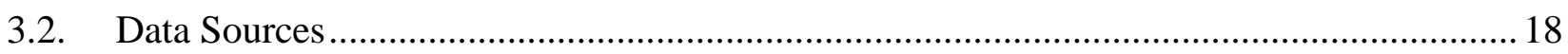

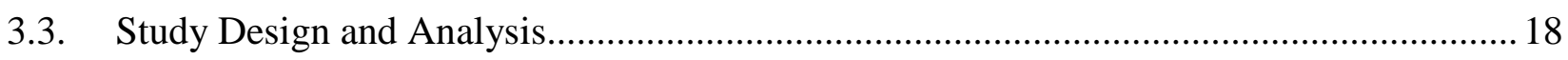

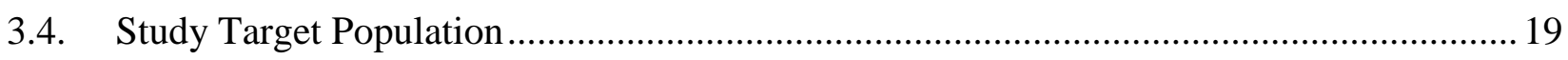

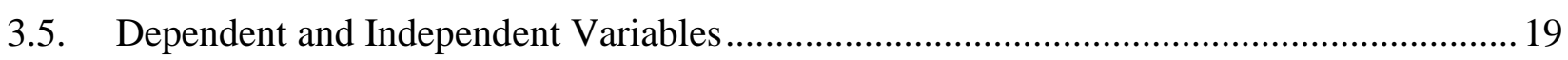

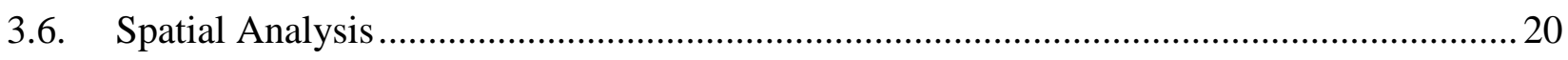

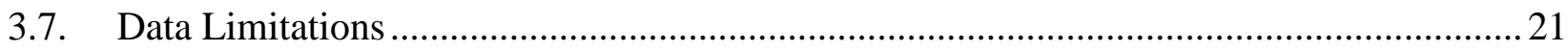

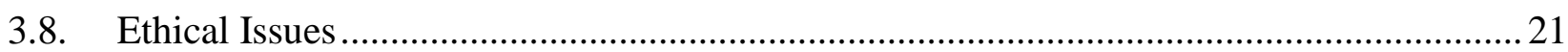




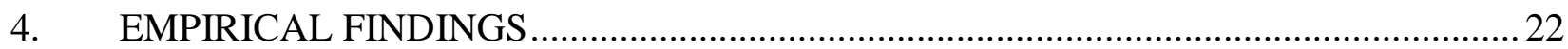

4.1. Levels, Patterns and Labour market indicators of internal migrants employed and unemployed in Gauteng South Africa, 2011 ......................................................................... 22

4.1.1. Labour market indicators of internal migrants by Province of previous residence in

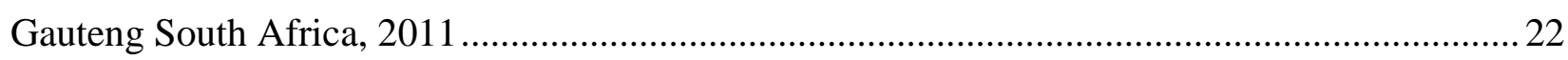

4.1.2. Levels and Patterns of internal migrants employed and unemployed in Gauteng South

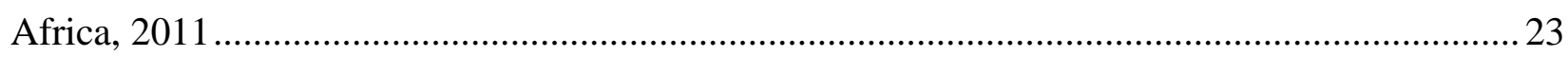

4.2. Test of Association and Predictors of internal migrants being employed in Gauteng, South

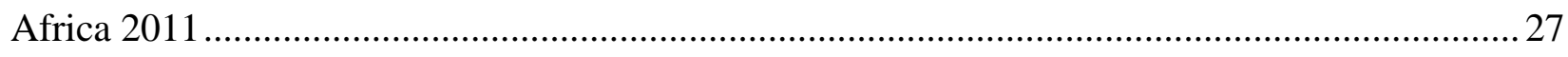

4.3. Spatial settlements of internal migrants employed and unemployed by Main Place in

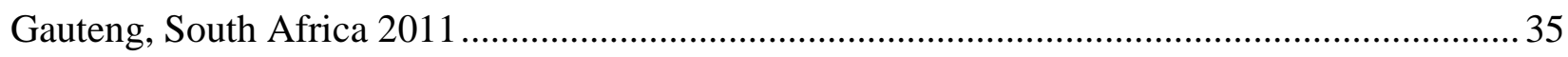

5. DISCUSSIONS, CONCLUSIONS AND RECOMMENDATION ................................ 41

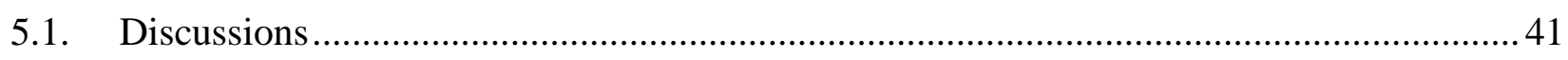

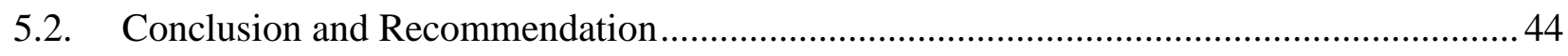

5.3. Recommendation for Further Studies....................................................................... 45

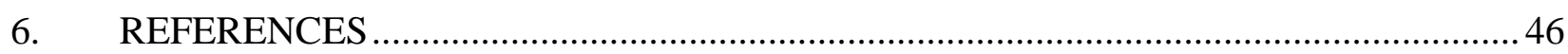




\section{TABLES}

Table 1: Table showing the selected individual and socio-economic characteristics, response categories and the data source used in the study 20

Table 2: Labour market indicators of internal migrants by Province of previous residence in Gauteng South Africa, 2011 22

Table 3: Distribution of internal migrants employed and unemployed by selected individual and socio-economic characteristics in Gauteng South Africa, 2011

Table 4: Individual and socio-economic factors significantly associated with internal migrants being employed in Gauteng South Africa, 2011 27

Table 5: Binary logistic regression showing odds ratios (OR) of the likelihood of selected individual and socio-economic characteristics predicting internal migrants being employed in Gauteng South Africa, 2011

Table 6: Binary logistic regression model predicting the likelihood of intervals of internal migrants being employed at their Province of previous residence (i.e. province of origin) compared to province of present residence (i.e. Gauteng) 


\section{FIGURES}

Figure 1: Levels of migrants and non-migrants employed and unemployed in Gauteng, 2011 ........23

Figure 2: Pattern of employment and unemployment by functional age groups in Gauteng, 2011 ..23

Figure 3: Patterns of internal migrants employed and unemployed by Sex in Gauteng, 2011.........24

Figure 4: The participation of internal migrants in different industries by sex in Gauteng, 2011....24

Figure 5: spatial settlement of employed internal migrants in Gauteng by Main Place, 2011 ...........35

Figure 6: Spatial settlement of the unemployed internal migrants in Gauteng by Main Place, 201136

Figure 7: Settlement by metro: employed migrants in Ekurhuleni, 2011 .......................................36

Figure 8: Settlement by metro: unemployed migrants in Ekurhuleni, 2011 ................................37

Figure 9: Settlement by metro: employed migrants in the city of Johannesburg, 2011 ...................38

Figure 10: Settlement by metro: unemployed in the city of Johannesburg, 2011 ...........................38

Figure 11: Spatial settlement by metro: employed migrants in City of Tshwane, 2011...................39

Figure 12: Spatial settlement by metro: unemployed migrants in City of Tshwane, 2011................39 


\section{ABBREVIATIONS AND ACRONYMS}

Central Business District (CBD)

Government Communication and Information System (GCIS)

1,11

Gross Domestic Product (GDP)

National Development Plan (NDP)

National Spatial Development Perspective (NSDP)

National Urban Development Framework (NUDF)

Odds ratio (OR)

28, 30, 33

United Kingdom (UK)

United States of America (USA)

10,12

South African Cities Network (SACN)

$1,2,17$ 


\section{CHAPTER 1}

\section{INTRODUCTION}

\subsection{Background and rationale}

Historically migration in South Africa has been influenced by past policies that controlled the movement of black people and their settlement patterns (Todes et al, 2010). The system of apartheid was aimed at keeping a majority of the black people in the former homelands which were mainly rural and lacked economic opportunities. South Africa revealed an uneven development profile that was biased in favour of urban areas resulting in an overconcentration of wealth assets, purchasing power and economic activities and many other services while rural areas were left underdeveloped and neglected (Ajaero \& Onokala 2013). The system condemned many people mainly blacks to a life of poverty and underresourcefulness. The government also enacted other laws that saw about 3.5 million people, mostly Africans forced to move out of the metropolitan areas and small towns to remote rural towns (Kok et al, 2006). The control of movements through legislation and other means served to entrench internal migration in the economic system (Posel, 2003).

According to Todes et al (2010) the policies of controlled movement and settlement patterns started to break down towards the mid-1980s resulting in larger numbers of people moving to the cities. It is against this background that provinces with better quality of life prospects experienced high influx of migrants from the other provinces in the period leading to 1994 and the trend seems to be continuing (Development Policy Research Unit, 2005). The abolishment of the laws that control movement meant that the government had to start to also explore options to accommodate the poor internal migrants in the urban centres (Kok et al, 2006).

Migration to Gauteng from all other provinces has always been higher than to other provinces in South Africa. The patterns of movement have contributed to make Gauteng the most populous province of more than 12 million people with a geographic land area of $18178 \mathrm{~km}^{2}$ (GCIS, 2013). From 1996 to 2003, Gauteng experienced gross domestic product (GDP) growth of 3.7 percent per annum against the national average of 2.5 percent and higher than all other provinces (SACN, 2006). The metros in Gauteng accounts for 25 percent of all employment in South Africa, and the province experienced high levels of GDP growth in its 
metros of between 4.7 percent and 5.5 percent over the period 2001 to 2004 (SACN, 2006). The economic growth created jobs but still at a rate lower than population growth (Todes et al, 2010). The high rate of migration to Gauteng created other poverty associated problems and resulted in the sprawling of the informal settlements and the growth of an informal economy. One such challenge was the settlement of migrants which the post-1994 government tried to address by prioritising the delivery of housing in the cities. Economic reasons and the general need to improve the quality of life are the main drivers of migration (Mberu, 2006). This does not just apply to South Africa but it is a general trend in most developing countries and according to SACN (2016) it is also a global trend.

The labour force is defined in terms of international standards as all the persons aged between 15 and 64 who supply labour for the production of goods and services. It includes the employed, self-employed, those who are assisting in a family business without pay and the unemployed who actively looked for employment over the last census period (Odimegwu, Frade, De Wet and Adenine, 2016). The employed refers to those who either work full time or part-time. According to Bundlender (2014) unemployment can be classified as either an official rate or an expanded rate. The expanded rate includes the official rate and the discouraged job seekers.

The internal migrants in this instance refer to those people who changed their province of residence within the borders of the country between 2001 and 2011 as indicated in census 2011. These are either permanent migrants or labour migrants, i.e. those who migrated for economic reasons and desire to go back to their provinces of origin later in life. There were approximately 5.6 million people in South Africa who changed residence between 1996 and 2001 (Statistics SA, 2005).

The population of all the provinces increased except in Northern Cape but Gauteng experienced the highest increase during the same period. Using the variables province of previous residence and province of usual residence, more than 700000 people migrated to Gauteng over the period 1996 to 2001 and this made up approximately 41percent of all internal migrants during the period (Statistics SA, 2005). The 2011 census data on migration was based on the reference period from October 2001 as asked in the questionnaire. Gauteng again had the highest number of migrants over the period 2001 to 2011, i.e. more than 1.4 million people, forming approximately 45 percent of all the migration to provinces in the period (Statistics SA, 2012). 
Broadly, various contemporary studies have focussed on internal migration in South Africa. The Development Policy Research Unit (2005) and Kok et al (1993) studied effects of internal migrants to Gauteng on infrastructure. Zuberi and Sibanda (2004) looked at migration patterns in post-apartheid South Africa. However, none of those studies focussed specifically on employment analysis of internal migrants to Gauteng specifically using the census 2011 data. A more recent cross-sectional data collected at a point in time as compared to that used by earlier studies in the country. Also, no study has done so looking at the special distribution of the subject matter in Gauteng, with the view of unveiling the distribution pattern in the province. This study is therefore designed to address these concerns.

\subsection{Problem statement}

The National Urban Development Framework (NUDF) provides a common nationwide view on how to build the capacity of South Africa's towns, cities and city regions to achieve their full potential of shared growth, environmental sustainability and social equity (South Africa, 2009). In order to achieve the intended objectives, the framework developed strategic outcomes and indicators. One strategic outcome focuses on growth in job creation and more incorporation of migrant communities into the society. The National Spatial Development Perspective (NSDP) 2006 notes that government has the responsibility to grow the economy and generate jobs (South Africa, 2007). The country is however battling with spatial inequalities in economic opportunities which are mainly the legacy of apartheid spatial planning.

The unemployment rate in Gauteng ranged from 26.7 percent in quarter one of 2008 to 29.9 percent in quarter four of 2011. It reached the peak of 32.8 percent in quarter three of 2010. Although the percentages are not the highest compared to all other provinces, the actual numbers of unemployment are the highest (Statistics SA, 2015).

According to Todaro (1980) migration to urban areas increases the number of job-seekers. The argument is that the rate of migration usually exceeds the rate of job creation and the capacity of the industry and social service to effectively absorb labour (Todaro 1980). The surplus labour that has not been absorbed becomes a burden to the region in a quest for survival. The government acknowledged this view that migration to urban areas results in limited economic opportunities and increasing poverty with all of its associated problems (South Africa, 2015). The National Development Plan (NDP) 2030 states that migration to urban areas is a global phenomenon (South Africa, 2012). 
In South Africa agricultural workers leave the land of usually subsistence farming for urban employment. The challenge is to establish if the implementation of NUDF is achieving this stated outcome of job creation and whether there is a difference in terms of spatial settlement between the employed and the unemployed migrants in Gauteng. The study is attempting to analyse internal economic migrants in Gauteng province in 2011 in terms of the NUDF and NDP and the spatial differences between the employed and unemployed migrants.

\subsection{Research questions}

- What are the levels and patterns of internal migrants employed and unemployed in Gauteng by selected individual and socio-economic characteristics?

- What are the individual and socio-economic factors that are significantly related with internal migrants being employed and not employed in Gauteng?

- Are internal migrants better able to secure employment in the province of previous residence (where they originally came from) compared to their province of current residence (i.e. Gauteng)?

- How are the spatial settlement patterns of employed and unemployed migrants in Gauteng?

\subsection{Aims and Objectives}

\subsubsection{Aims}

The aim of the study is to establish factors influencing labour force participation of internal migrants in Gauteng in 2011. It is also to establish if there is spatial variance between internal migrants who are employed and those unemployed.

\subsubsection{General objectives}

The general objective of the study is to critically examine the individual and socio-economic characteristics associated with internal migrants labour force participation and their spatial settlement pattern in Gauteng, South Africa, 2011.

\subsubsection{Specific objectives}

- To examine the levels and patterns of internal migrants employed and unemployed in Gauteng by selected individual and socio-economic characteristics. 
- To examine the individual and socio-economic factors significantly related with internal migrants being employed and not employed in Gauteng.

- To establish if internal migrants are better able to secure employment in the province of previous residence (where they originally came from) compared to their province of current residence (i.e. Gauteng).

- To establish the spatial settlement patterns of employed and unemployed migrants in Gauteng

\subsection{Hypothesis}

- The individual and socio-economic characteristics are not significantly associated with employment of internal migrants in Gauteng.

- There is no variance in the spatial settlement patterns the employed and unemployed internal migrants in Gauteng. 


\section{CHAPTER 2}

\section{LITERATURE REVIEW}

\subsection{Introduction}

The developed and developing countries have been experiencing an increasing rate of migration over the past decades (Massey, 1993). People have always been moving between countries and within countries in search of perceived or real opportunities (Ajaero \& Onokala 2013). At the turn of the millennium the migration trend in South Africa was mainly from rural to urban (Kok et al, 2003).

Migration is a complex and diverse concept that cannot be explained by a single theory (Arango, 2000 and Kok et al, 2003). The aim of building a migration theory is mainly to try to narrow it to focus on research topic (Arango, 2000). The migration of people especially from rural to urban areas is not unusual but in recent times there was an increase in voluntary migration by low skilled as well as high skilled workers to urban areas amongst the poor in developing countries (Ajaero and Onokala 2013). The pattern of migration in South Africa is similar to other developing countries as it mainly entails the movement of people from rural to urban areas and is also associated with labour migration (Kok et al, 2003).

Gauteng has always relied on immigrants for the supply of labour since the discovery of mineral wealth (Oosthuizen and Naidoo, 2004). The literature will focus on economic theories that outline labour migration. The theories that will be outlined are neoclassical theory, new economics of migration and dual labour market theory.

\subsection{Theory of migration}

The theory of migration was primarily conceptualised by Ravenstein in his laws of migration (Arango, 2000 and Lee, 1966). He suggested that motivations for migration may range from oppressive laws to unattractive climate in different countries but none counts as much as the desire by the people to better themselves economically (Arango, 2000). The laws of migration provide a summary of the patterns and trends of migration. They indicate amongst others that migration is mostly prevalent over short distances and usually from rural areas to urban areas. Over long distances, migrants are attracted by the centres of commerce and industry while the overall motive for migration is to find employment. 
These laws were revised by Lee (1966), who proposed a new migration theory framework which postulated that the decision to migrate can be explained under the following headings: Factors associated with the area of origin and of destination; intervening obstacles; and personal factors. The intervening obstacles include the cost of migration, legal restrictions and social structures in the area of origin, and depending on the ability of the person who is aware of those obstacles and is able to overcome them, they can serve as deterrent to migration (Lee, 1966 and Kok et al, 2006).

In South Africa, the intervening obstacles were legal restrictions based on ethnicity and language. This combined with poor development in former homelands ensured that most black people lived in poverty and without access to opportunities. The abolishment of laws restricting movement saw an increase in the number of black people moving to the cities with the hope of getting jobs. The international migrants are faced with the challenge of legal documents to be eligible to enter the country of destination and they must also abide by the laws of the country of destiny.

The factors at both area of origin and destination act as either pull or push factors. Pull and push factors can be used to explain most of the migration theories that are both economic and non-economic (Kok et al, 2006). In the context of developing economies, a pull is associated with opportunities while a push is associated with poverty (UNDP, 1994). People respond differently to intervening obstacles both at place of origin and destination and this is what makes migration selective (Lee, 1966). This means not everyone can migrate because individual characteristics, pull factors in the area of destination and push factors in the area of origin play a role in the migration decision-making.

Personal factors that might affect migration are identified as amongst others: personal intelligence; sensitivities; awareness of the area of origin and destination (Lee, 1966). One of the objectives of this study is to analyse the probability of finding employment as internal migrants in Gauteng compared to their province of origin in 2011. The findings will inform policy makers on the future expectations of migration patterns in response to employment.

\subsection{Macro and micro perspective of neoclassical theory}

The neoclassical theory is currently dominating the literature in explaining the causes of migration, and it argues that the main driver of migration is the relative costs and benefits of economic considerations (Todaro and Smith, 2006). It classifies the macro and micro level 
factors that cause migration. At macro level, the neoclassical theory of migration argues that both internal and international migration is determined by geographic differences in labour supply and demand and wage differentials between two areas (Kurekova, 2011 and Kok et al., 2003). This approach indicates that internationally countries that are endowed with high abundance of labour relative to capital are generally characterised by low market wages while those with high abundance of capital relative to labour have higher market wages (De Haas, 2007). The wage differentials between the regions will result in workers moving from lowwage areas to high-wage areas.

The link between the neoclassical model and employment is so strong that it is believed that if wage differentials could be eliminated then migration will end (Kok et al, 2003). The origin of neoclassical theory can be traced back to Lewis' two-sector model although the model was more focussed on development than migration (Todaro and Smith, 2006). According to Lewis (1954) the economy is made up of two opposite sectors: One is traditional and dominated by a subsistence sector with no marginal labour productivity while the other one is urban with a high labour productivity industrial sector. The traditional sector contains surplus labour because according to the model it can be withdrawn anytime without any consequences of disrupting rural agricultural output. The model focusses mainly on labour transfer from the rural traditional sector to urban industrial sector, which is assumed to attain full employment.

The Lewis' two-sector model was criticised for being unrealistic in some respects. Todaro and Smith (2006) stated that the assumption of full employment in the urban industrial sector is not consistent with reality. Ghatak (2003) estimated that urban unemployment in developing countries is between 15 and 20 percent of the total urban labour force. As a result Ghatak (2003) concluded that the Lewis' two-sector model overestimated the capacity of the urban sector to create employment and absorb both the unemployed and underemployed.

Todaro (1980) tried to modify the Lewis' two-sector model by developing the Harris-Todaro model. It argues that rural-urban migration happens even if there is urban unemployment because the decision to migrate is based more on expected rather than actual earnings. At the micro level, the individuals are seen as rational actors whose decision to migrate is based on positive return usually in the form of monetary compensation (Massey at al., 1993). The decision to migrate is based on the desire of the migrants to maximise their expected gains 
from income differences between rural and urban areas and the probability of finding employment in the urban area (Todaro, 1980).

Migration involves costs, which in most cases the poorest people and countries cannot afford (Kurekova, 2011). The argument is that migration tends to be hump-shaped as migration only increases with one's ability to bear the costs. According to Guriev and Vakulenko (2013), the low migration rate in poor areas of Russia in the 1990s was as a result of underdeveloped financial markets, but when income started to increase in the 2000s, migration increased as well. The study conducted in Egypt by Adams (1993) to understand the relationship between income and migration found that the relationship is U-shaped. The middle income males were found to have the highest propensity to migrate. The results were however found to be different when land is factored in. It was found that the poor and landless were more likely to migrate than the middle income.

According to Todaro (1969) the micro approach of individual decision making of neoclassical theory is also called human capital theory. The theory adds to the neoclassical theory by including demographic characteristics of an individual as an important determinant of migration (Bauer and Zimmermann 1999). The factors that strongly influence migration were identified as human capital endowment, skills, age, marital status, gender, occupation, and labour market status (Kurekova, 2011).

Bauer and Zimmerman (1999) contend that migration is an individual investment that depends on factors such as age, gender and education and potential for higher returns in the area of destination than the area of origin. They indicated that there is a likelihood that migration will decrease with age because there are little lifetime benefits for older people and will increase with education. The argument is that those with higher levels of education are able to access information and to reduce the risk of migration. The argument that migration is likely to decrease with age and increase with education was supported by Lucas (1997) who indicated that in developing areas, the rural-urban migration is dominated by young adults and those with higher levels of education than the rest. Lucas (1997) further stated that in the case of Africa and Asia, migration is male dominated. The proportion of working age population born outside Gauteng is about 82 percent (Oosthuizen and Naidoo, 2004).

The findings of the study conducted in the USA reflects the model for developed countries while those conducted in Brazil and South Africa are a reflection of the model for developing countries. According to Black (1983) in a study conducted in the USA, it was found that 
migration is higher amongst the unemployed compared to the employed. The reason was centred on the opportunity cost of such migration which is higher for employed people compared to the unemployed. The married females were found to be more likely to migrate than those not married. This went against the generally upheld notion that married females are less likely to migrate.

A study conducted in Brazil found that migration is dominated by people with poor skills to be absorbed in the economy that require industrial skills (Fischlowitz and Engel, 1969). Due to a lack of skills migrants only move from rural unemployment and underemployment to the same conditions in the urban areas which only add burden on public and social services. The findings in this case agree with a two-stage process of migration in developing countries (Todaro, 1969). The first stage is the migration of unskilled workers from the rural to urban areas, thus spending time in the informal sector and finally getting a formal sector employment in the second stage. In South Africa the dominant in proportion of men migrating to Gauteng is influenced by historical and continued demand for labour in heavy industry and mining (Oosthuizen and Naidoo, 2004)

Posel (2003) found that gender plays a role in migration in South Africa. The internal structures of control in rural communities were such that females should remain at home while men migrate to work in the cities and send remittance home (Walker, 1990). This explains why men have always been economically more dominant. The study by Posel (2003) further found that there has been a consistent increase in the number of female labour migrants between 1993 and 1999 which could be attributed to the loosening of internal structures of control. The study also found a decreasing trend in marriage of female migrants.

According to Fauvelle-Aymar (2014) who analysed the Quarterly Labour Force Survey quarter three of 2012 concluded that the median age of internal migrants is 32 years and the average age is 34.72 years. This category of the population is the youngest compared to international migrants and non-migrants. This condition satisfies in part the human capital theory notion that migration decreases with age. The median age of international migrants was found to be 35 years. The study didn't find much difference in migration between males and females while blacks were found to be a majority amongst migrants compared to other population groups. When using the official unemployment rate the domestic migrants were found to be largely unemployed. 
Gauteng has the highest level of per capita income in the country (GCIS, 2013). The study from the Development Policy Research Unit (2005) found that in the case of South Africa that migrants to Gauteng usually have higher levels of education compared to residents and are therefore better employable than the non-migrants. As a result they also tend to have a higher labour force participation rate (Budlender, 2014). There is a positive relationship between the earnings of the migrants and their duration of stay in the settlement area (George, Stephen and Stephen, 1992). If this finding holds, then it is expected that there will be variations in income trends over the period.

The neoclassical migration theory acknowledges that migrations are a product of push and pull factors (Kok et al., 2006). The prospects of getting a job and earn an income as pull factors are usually stronger.

\subsubsection{Criticism of the neoclassical theory}

The neoclassical theory is regarded as the best theory of explaining migration because it has the advantage of combining the macro elements of structural differences with micro elements of individual decision-making perspective (Arango, 2000). The theory also enjoyed the advantage of being critiqued and modified to better reflect modern reality. The Lewis twosector model was modified in the Todaro-model and later the Todaro-model itself was modified to become more realistic (Bauer and Zimmermann, 1998).

The modifications included the expansion of the model beyond employment and wage differentials as the driving forces of migration to include opportunity costs of migration, the travelling costs, temporary unemployment while moving and settling at the area of destination, and the psychological costs of migration (De Haas, 2007). Even if that was the case the theory had its shortcomings which, key amongst them, is its ignorance of the existence of market imperfections and structural constraints especially in developing countries (De Haas, 2007 and Arango, 2000). The theory was further criticised that it treats societies as homogeneous with static perspectives and all migrants as labour migrants.

The new migrants from rural to urban areas face voluntary unemployment because the urban industrial economy has less capacity to create employment relative to the rate of migration (Todaro, 1980). When faced with this situation, the migrants basically have two options to follow: (a) To accept the job in the informal sector with the hope of moving into high paying formal sector later on, (b) reject the informal sector employment, remain unemployed but 
invest more in information and formal sector job search (Stark, 1991). The migrants will choose the low paying informal sector with the hope of finding formal sector employment later on (World Bank, 2006).

The neoclassical theory was further criticised for looking at wage differentials as the only factor that migrants base their decision to migrate on. According to social-structural theories, rural tenure arrangements can also retard migration (Standing, 1981). This, Standing (1981) argues, can reduce rural-urban migration even if the urban sector is modern and able to absorb surplus labour.

\subsubsection{Application of neoclassical theory}

The application of neoclassical theory focusses on different countries that are both developed and developing. The aim is to try to test using case studies whether it is the developed or developing countries that exhibit the characteristics of neoclassical theories.

\subsubsection{Application of neoclassical theory in developed countries}

Morrison and Clarke (2011) studied internal migration in the UK, USA and Australia and found that less than a third of migrants are motivated by employment reasons. They also studied the case of New Zealand and found that only a minority of working-age migrants move for employment reasons. The main reasons for migration were found to be the consumption of amenities offered by the local government and social networks provided by family (Clark et al., 2003).

The probability of finding employment in the urban area as the basis of the decision to migrate can be explained by historical movement of the Americans unskilled labourers between agriculture and industry during the depression decade (Todaro, 1969). The study found that at the time when urban wages were higher and falling less rapidly than rural agricultural wages, there was reverse migration from urban areas to rural areas. It is argued that this migration was employment induced as people perceived the agricultural sector as offering better job prospects.

\subsubsection{Application of neoclassical theory in developing countries}

In trying to solve the problems of urban unemployment as indicated in the neoclassical theory, Kenya instituted what it called a tripartite agreement between government, private sector and the trade unions (Todaro, 1969 and Ghatak, 2003). The government agreed with 
the private sector to increase employment and the trade unions to moderate their wage demands. The aim was to eradicate unemployment in the capital Nairobi. This strategy was described as a failure because it resulted in more rural-urban migration with the hope of being employed. In a short period of time the employment rate dropped to the former level due to attrition and more unemployment due to new migrants (Todaro, 1969).

The likelihood to migrate in Ghana was as a result of pull factors at individual level and push factors at community level (Ackah and Medved, 2010). The community level variables are common to both migrants and non-migrants and were therefore interpreted as push factors. The push factors follow regional boundaries in Ghana because the location of different ethnic groups follows regional borders. The pull factors were an expectation of higher wages brought about by differentiation in demand and supply of labour as postulated by the neoclassical theory. The study also found that the people who are likely to migrate are more educated members of the community in a country with a generally lower average level of education.

A study in Brazil found that internal migration is highly responsive to wage differentials as postulated in the neoclassical theory (Sahota, 1968). This means people migrated from areas with lower wages to those with higher wages. Internal migration was found to be inversely related to distance such that as the distance increases, migration decreases. According to Sahota (1968) the costs of travelling, associated costs and investments play a role in migration determination.

\subsubsection{Summary of the application of neoclassical theory}

The neoclassical model is considered more effective in explaining internal migration in developing countries more than in developed countries (Morrison and Clarke, 2011). The reason is that there are high levels of disparities between areas in developing countries compared to developed countries. The developed countries are considered to have high levels of job opportunities across wide range of locations (Morrison and Clarke, 2011). The relationship between urban migration and development is an issue of global debate (Ajaero and Onokala, 2013 and Shimeles, 2010). Urban migration is more prominent in developing countries. This is mainly due to inequality in wealth and resources between rural and urban areas. According to Ajaero and Onokala (2013) the migrants have to earn an income to be able to survive and to remit it back to their places of origin. 


\subsection{The New Economics of Migration}

The new economics of migration is a theory that developed from neoclassical theory to challenge some of its assumptions and conclusions (Massey et al., 2003). According to Arango (2000) it can either be seen as criticism of the micro version of neoclassical theory or as supplement to it that seeks to enrich it with amendments and additions. According to Stark (1991) migration is not always an individual maximizing behaviour, but often involves other person or a group of other persons like family. Stark (1991) criticised the neoclassical theory position that the failure of labour migration to follow wage differentials implies irrationality and argued that there could be other issues like income uncertainty and relative deprivation that have to be considered. The third factor is assumed to be market imperfections and incomplete markets.

Migration is not an individual rational choice but a family decision of diversification. The aim is not to maximise income but to diversify income streams so as to minimise risk of unemployment and income failure and to access scarce investment capital (Arango, 2000; Massey et al., 1994 and Massey et al., 1993). The migration decision by households aims to improve both the relative and absolute income (Kok et al 2003). The absolute income is what renders the household materially better-off than the previous period while relative income means being better-off compared to other households in the community.

The need to migrate is equivalent to modern day private risk insurance which in most cases does not exist in developing countries, so this market failure creates strong push for international migration. Stark (1991) noted that the only difference between neoclassical and new economics theory is the actors in the decision-making process. The neoclassical theory emphasise individual decision-making while the new economics theory emphasise the group of actors like family. He also noted that migration from rural to urban areas creates problems of unemployment, underemployment and low income resulting in urban labourers living in deprivation that threatens political order. The new economics of migration model was criticised for assuming that all members of households are homogenous with same interests (Kok et al., 2003). In a study conducted in Mexico it was found that internal migration is less effective in improving conditions of relative deprivation than international migration due to high income in developed countries (Massey et al., 1994). 


\subsection{Dual Sector model}

The dual sector theory is a macro perspective theory that links migration to structural changes in the economy and also explains migration from the demand side (Kurekova, 2011). According to this model migration is a response to intrinsic labour demand of industrial economies which locals are not prepared to accept (Massey et al., 1993). The theory was developed by Piore (1979) who argued that push factors to migration do not exist, but only pull factors due to permanent demand for labour in industrialised economies. The model is mostly suited to international migration but the analogy can also be applicable to internal migration status. According to Kok et al. (2003), the theory factors in structural inflation, job motivation, economic dualism and labour supply demography.

Economic dualism means the structure of an economy is both capital intensive and labour intensive (Massey et al, 1993). Capital intensive sector employs both skilled and unskilled workers while labour intensive sector employs proportionally more unskilled workers (Kurekova, 2011). According to Massey et al. (1994) the two sectors include the primary sector that offers high income, job security and pleasant working conditions and secondary sector offering low income and unpleasant working conditions.

Structural inflation happens when employers have to raise wages to attract low level unskilled workers as a result of a permanent need for low-wage workers in the developed economies that locals are not willing to fill (Arango, 2000). According to this theory, work and earnings confer status and prestige to the people and therefore locals are not prepared to take up existing positions at current wages because they argue that poor social status and increasing wages will only serve to upset relationships between status and remuneration as it would require that wages be increased at all levels (Massey et al., 1993). To compound the problem there is also a decline in low-wage labour participation by women and falling fertility rates in developed economies which reduces the number of people willing to work for low wages (Kok et al., 2003). The cost effective solution is to get low skilled migrants to work for low wages. According to the World Bank (2006) immigrants improve the efficiency of firms because they provide labour that can be employed in new locations and can also be hired and fired anytime.

It is difficult to verify this model empirically because it focusses on the demand side (Massey et al, 1993). The implication of the non-existence of push factors is that the study should focus on the receiving area and so the receiving area indicators should dominate predictive 
power (Kok et al., 2003). A study conducted in the Caribbean and South East Asia found that international migration from these countries to the United States continued even if the economic growth was higher than in the United States. The reason was the consistency of available low-wage jobs in areas like New York. This reflected bifurcated employment structure as postulated by the dual sector model (Kok et al., 2006).

In another study conducted in Japan, Green and Kadoya (2015) found that country's population is ageing and experiences a declining fertility rate. This creates a labour supply shortage that can only be filled by immigrants, especially in the unskilled low-wage job categories that locals are not prepared to engage in. According to Arango (2000) the theory better explains the side-by-side coexistence of foreign labour market and high rates of unemployment in many receiving countries.

The theory was however criticised for amongst others failure to explain differential immigration rates for advanced industrialised countries with similar economic structures and was also seen as distorting reality by ignoring push factors (Arango, 2000). Research on the dual sector model failed to clearly link immigration to a demand for unskilled workers in the secondary sector because international migrants also include refugees (Massey et al., 1994).

\subsection{The South African context of economic theory of migration}

The synthetic model of migration as postulated by Kok et al. (2006) is an attempt to come up with a comprehensive theory of migration conceptualising spatial and individualised rewards to labour migration. The spatial rewards act more like a macro perspective of the neoclassical theory while individualised rewards is the equivalent of human capital theory at the micro level. Individuals migrate with the hope of gaining spatial and economic rewards. The spatial reward is the ability of one area to satisfy human needs more than the other area. In South Africa the areas that were dominated by homelands are less developed than cities. According to Ajaero and Onokala (2013) the uneven development between the city and its surrounding rural hinterlands makes city life more rewarding. The movement between these rural hinterlands and cities are largely the products of push and pull factors. The push factors that tend to drive individuals away are varied but those that make it difficult for individuals to stay in the area of origin are mainly unemployment, poverty, crime and to some extent land tenure arrangements (Kok et al., 2006). 
The government has provided basic services like water and electricity in rural areas but the economy is still dominated largely by subsistence agriculture and low wages. The people who work in this sector tend to migrate to urban areas but often end up taking jobs in the informal economy (SACN, 2006). According to Cross (2009) understanding spatial settlement is another challenge. She argued that most migrants to the urban areas settle in the shacks as townships are already overcrowded and state subsidised low-cost housing has long waiting lists. This results in the mushrooming of shacks and puts a strain on infrastructure and low cost housing

Individualised rewards are human capital rewards that accrue to oneself as a result of investment in oneself. According to Rempel (1981) those who are better educated engage in rural-urban migration to realise their return on education. The other demographic factors that bring individualised results could be gender. Being a male or a female can determine the type of employment in other countries. A study conducted by Zwiech (2008) in Poland concluded that females find it more difficult to find employment in most European Union member states including Poland. This study will also look at the spatial patterns of settlement of migrants in Gauteng. 


\section{CHAPTER 3}

\section{METHODOLOGY}

\subsection{Introduction}

This section will discuss the general methodology used in the study. It will introduce the data sets used in the analysis, the study design and statistical techniques applied. This chapter will also highlight some limitations associated with the data used in the study.

\subsection{Data Sources}

The study uses the 10 percent Census 2011 dataset that was collected by Statistics South Africa. The census 2011 dataset provides data at the individual and household level. The study specifically focusses on individuals who migrated to Gauteng from the eight provinces in South Africa between 2001 and 2011 as collected in census 2011. The census data is described as most comprehensive in analysing migration and employment although it also has its own limitations (Zuberu and Sibanda, 2004).

\subsection{Study Design and Analysis}

The study adopted a quantitative approach in which an analysis was done at three levels using the descriptive and inferential statistics. These levels are the univariate, bivariate and multivariate levels respectively. The frequency tables, graphs of cross-tabulations were done at univariate level. At bivariate level a chi-square test was used to test and identify the significant and associated selected individual and socio-economic characteristics of labour force participation and employment patterns of internal migrants in Gauteng.

The multivariate level analysis served to identify the characteristics significantly predicting the outcome variable of the study. It specifically tests the levels at which significant individual and socio-economic characteristics predict the likelihood of being employed in Gauteng. Here, the binary logistic regression model option was used because the outcome variable of the study enabled binary categorization. It also enabled testing the likelihood of migrants being employed in Gauteng compared to their area of origin. Labour force participation will be inclusive of an expanded definition of unemployment. As a result, people who have indicated that they are not available for employment but fall within the 
economically active population age-range, will be classified as unemployed. The output will give a snapshot overview of the patterns in 2011.

According to Zuberu and Sibanda, (2004), the logistic regression model can be used to measure the effects of predictor variables on the likelihood of participating in the labour force or of being employed at a multivariate level (Zuberu and Sibanda, 2004). The model is also called the choice model because it allows the use of binary dependent variables in the assessment of binary choices (Riharme, 2002). The regression model is given by the formula:

$$
\ln \left[\frac{\operatorname{Pr}(y=1 \mid x)}{1-\operatorname{Pr}(y=1 \mid x)}\right]=\sum b_{k} x_{i k}
$$

Where the left hand side $\ln \left[\frac{\operatorname{Pr}(y=1 \mid x)}{1-\operatorname{Pr}(y=1 \mid x)}\right]$ of the equation is the odds of being employed, $\mathrm{Y}$ is a function of predictor variables $X_{i k}$ and $b_{k}$ is the co-efficient. The study analysis will be carried out in a classified and joint (general) model respectively. The logistic regression analysis is used to model changing employment trends while controlling other demographic variables. The odd ratio and p-value results are analysed.

\subsection{Study Target Population}

The target population are the internal economic migrants in Gauteng, South Africa, that are between the ages of 15 and 64 years. The data is extracted from the 10 percent sample of the 2011 census. According to Budlender (2014) people aged 15-64 years are considered the standard working-age population in official statistics.

\subsection{Dependent and Independent Variables}

In the study the employment variable recorded to the binary option of Yes (1) and No (0) was used as the dependent (outcome) variable. Data on all relevant individual and socio-economic characteristics, as informed by available literature and the data set, were used as the independent variables. The study regards all the unemployed people including discouraged job seekers and those who are not economically active, but are within the age range of 15-64 as unemployed. The individual and socio-economic characteristics and their response categories used in the analysis of the study are as shown in table 1 below. 
Table 1: Table showing the selected individual and socio-economic characteristics, response categories and the data source used in the study

\begin{tabular}{|c|c|c|c|}
\hline \multicolumn{2}{|c|}{ Variables } & Response Categories & Data Source \\
\hline \multicolumn{4}{|c|}{ Demographic } \\
\hline 1 & Age & Age in completed years & Census 2011 \\
\hline 2 & Sex & Male or Female & Census 2011 \\
\hline 4 & $\begin{array}{l}\text { Population } \\
\text { group }\end{array}$ & $\begin{array}{l}\text { Black/ African, Coloured, Indian/Asian, } \\
\text { White and others }\end{array}$ & Census 2011 \\
\hline \multicolumn{4}{|c|}{ Socioeconomic } \\
\hline 5 & $\begin{array}{l}\text { Employment } \\
\text { status }\end{array}$ & $\begin{array}{l}\text { Employed, un-employed, not economically } \\
\text { active }\end{array}$ & Census 2011 \\
\hline 6 & $\begin{array}{l}\text { Work for } \\
\text { salary }\end{array}$ & Yes, No & Census 2011 \\
\hline 7 & Income & $\begin{array}{l}\text { Annual salary level R0-R2 } 457601 \text { or } \\
\text { more }\end{array}$ & Census 2011 \\
\hline 8 & $\begin{array}{l}\text { School } \\
\text { Attendance }\end{array}$ & Yes, No & Census 2011 \\
\hline 9 & $\begin{array}{l}\text { Highest } \\
\text { education } \\
\text { level }\end{array}$ & $\begin{array}{l}\text { No education, Primary, some secondary, } \\
\text { Secondary, Higher, other. }\end{array}$ & Census 2011 \\
\hline 10 & $\begin{array}{l}\text { Province of } \\
\text { residence }\end{array}$ & Nine (9) provinces of South Africa & Census 2011 \\
\hline 11 & Mother alive & Yes, No & Census 2011 \\
\hline 12 & Father alive & Yes, No & Census 2011 \\
\hline 13 & $\begin{array}{l}\text { Marital } \\
\text { status }\end{array}$ & $\begin{array}{l}\text { Married, Living together, N/married, } \\
\text { Widow, Separated and Divorce }\end{array}$ & Census 2011 \\
\hline 14 & Geo type & Urban, Rural & Census 2011 \\
\hline
\end{tabular}

\subsection{Spatial Analysis}

Spatial autocorrelation techniques will be used to analyse the settlement patterns of the employed and unemployed migrants in Gauteng at provincial level. Spatial autocorrelation measures the degree to which a set of features are spatially clustered or dispersed (Kekez, 2015). Dispersal means negative spatial autocorrelation while clustering means positive autocorrelation. Anselin Morans I analyse clusters and outliers by calculating the statistical significance of z-scores and p-values.

The output given are clusters of higher values (HH), lowers values (LL) and outliers wherein higher values are surrounded by lower values or lower values by higher values. The output will be analysed at main place level as recorded in the 2011 Census. An analysis will also include spatial settlement patterns at metro level. 
This will reveal the preferred destination of migrants and the differences in patterns at both provincial and metro level.

\subsection{Data Limitations}

The 2011 Census data that was used in the study has various limitation issues. It does not capture the reasons why people left their place of origin and why they settled at the destination. The research focussed only on internal migrants to Gauteng. It did not look at the out-migrants from Gauteng.

\subsection{Ethical Issues}

The study used secondary data already collected and processed by Statistics South Africa and thus, available for use in a 10 percent sample. As such it does not pose any ethical difficulties. 


\section{CHAPTER 4}

\section{EMPIRICAL FINDINGS}

4.1. Levels, Patterns and Labour market indicators of internal migrants employed and unemployed in Gauteng South Africa, 2011

\subsubsection{Labour market indicators of internal migrants by Province of previous residence} in Gauteng South Africa, 2011

Table 2: Labour market indicators of internal migrants by Province of previous residence in Gauteng South Africa, 2011

\begin{tabular}{|c|c|c|c|c|c|}
\hline \multirow[b]{2}{*}{$\begin{array}{c}\text { Province of } \\
\text { previous } \\
\text { residence }\end{array}$} & \multicolumn{5}{|c|}{2011} \\
\hline & Employed & Unemployed & $\begin{array}{c}\text { Discouraged } \\
\text { work- } \\
\text { seekers }\end{array}$ & $\begin{array}{c}\text { Not } \\
\text { economically } \\
\text { active }\end{array}$ & Total \\
\hline Western Cape & 3.6 & 0.4 & 0.1 & 0.9 & 4.9 \\
\hline Eastern Cape & 6.2 & 2.8 & 0.5 & 2.8 & 12.3 \\
\hline Northern Cape & 1.0 & 0.2 & 0.0 & 0.4 & 1.6 \\
\hline Free State & 4.6 & 1.2 & 0.2 & 1.7 & 7.6 \\
\hline KwaZulu-Natal & 11.3 & 3.6 & 0.6 & 3.9 & 19.4 \\
\hline North West & 6.1 & 1.7 & 0.3 & 2.4 & 10.5 \\
\hline Mpumalanga & 7.1 & 2.2 & 0.4 & 3.0 & 12.7 \\
\hline Limpopo & 15.6 & 7.1 & 1.0 & 7.2 & 31.0 \\
\hline Grand Total & 55.4 & 19.3 & 3.1 & 22.2 & 100.0 \\
\hline $\begin{array}{l}\text { Non-migrants in } \\
\text { Gauteng }\end{array}$ & 64.3 & 13.6 & 2.3 & 19.8 & 100.0 \\
\hline
\end{tabular}

Table 1 above shows labour market indicators of internal migrants by province of previous residence in Gauteng South Africa, 2011. It shows that employment rate was higher amongst non-migrants compared to migrants. In terms of migrants’ labour force participation, most migrants were employed while discouraged work-seekers are the least in the distribution. The highest percentage of employed migrants was from Limpopo, while the Northern Cape has the least percentage of employed migrants. The three categories: unemployed, discouraged work-seekers and not economically active were combined in one group classified as unemployed. The table shows that the highest rate of unemployed internal migrants is the not economically active population category. 
4.1.2. Levels and Patterns of internal migrants employed and unemployed in Gauteng South Africa, 2011

Figure 1: Levels of migrants and non-migrants employed and unemployed in Gauteng, 2011

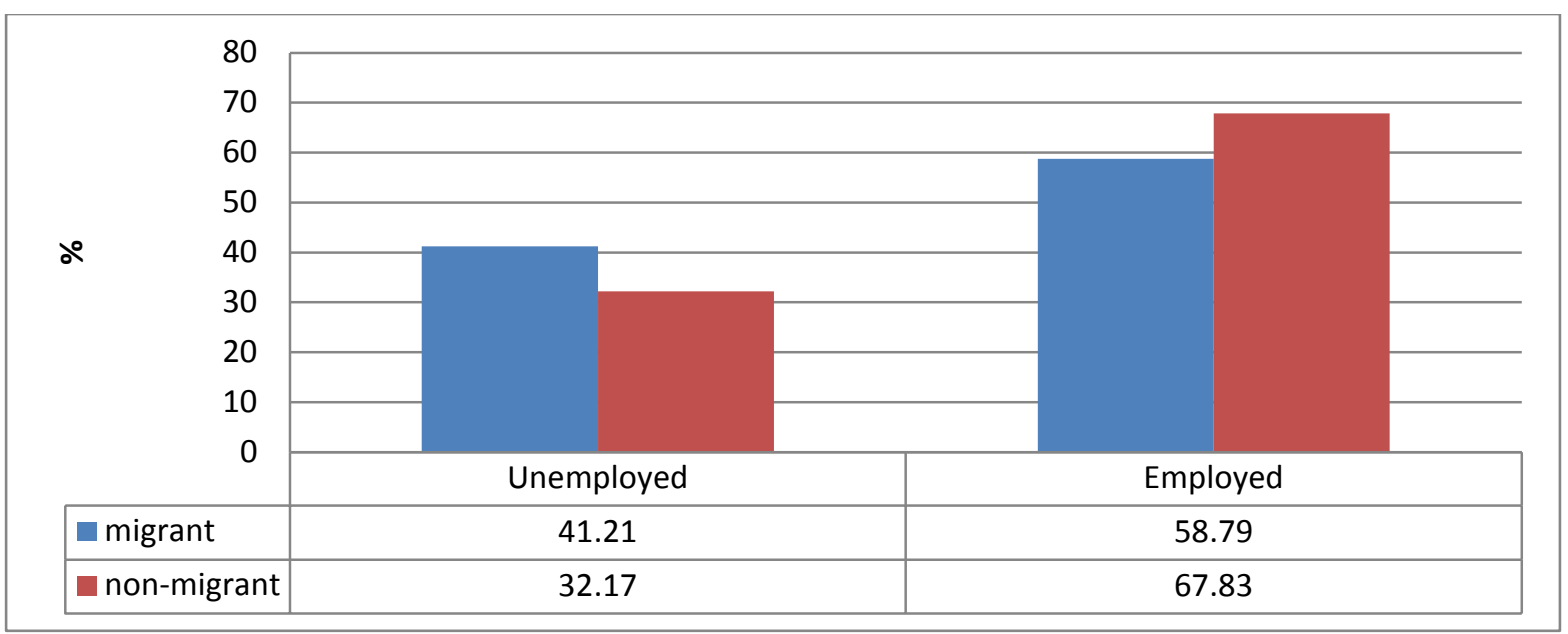

The figure above shows the percentages of migrants and non-migrants that are employed and unemployed in Gauteng, 2011. The result shows that there are more non-migrants employed than labour migrants.

Figure 2: Pattern of employment and unemployment by functional age groups in Gauteng, 2011

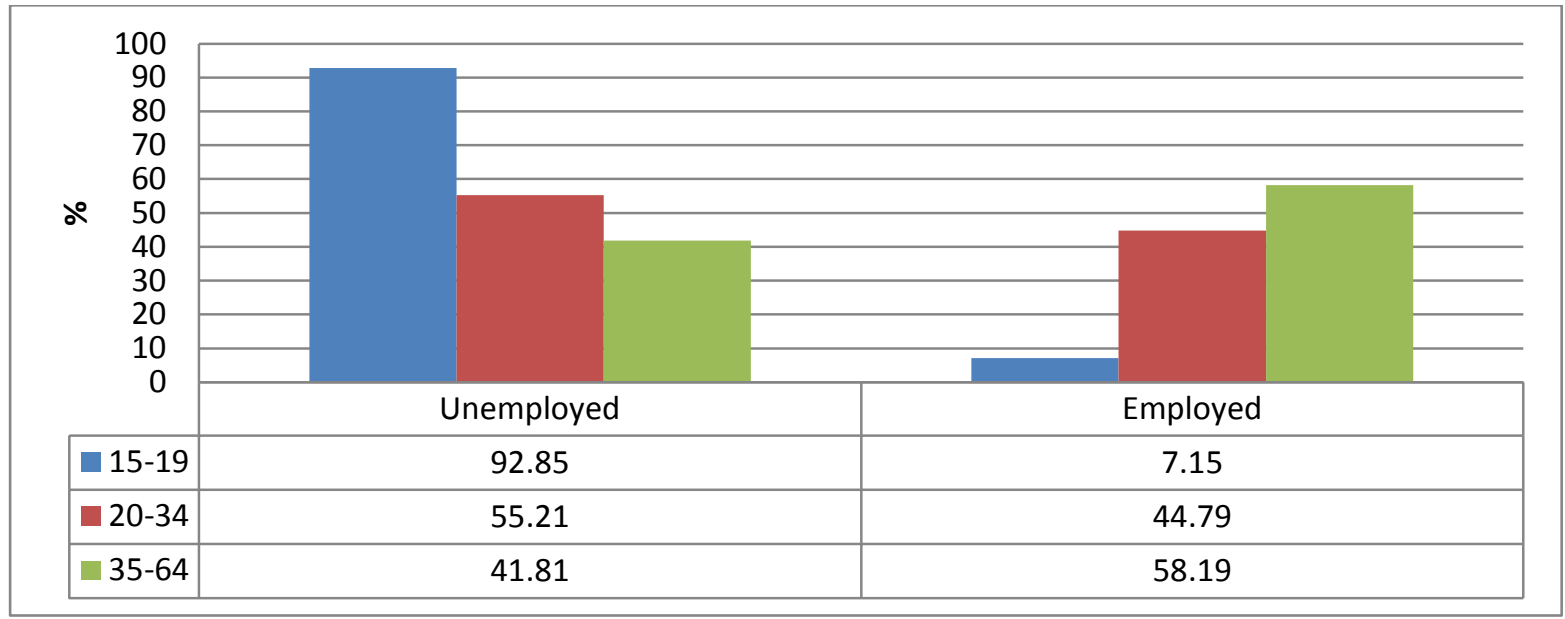

For the purpose of analysis, three functional age groups were created: 15-19; 20-34; and 3564. The rationale for re-classifying these age groups is because our subject matter (among others), is in the area of economic labour force participation. Therefore the need to re-classify into functional age groups is in line with demographic (analytical) expectation, creating room for a more efficient and relevant result. And in seeing to this, effectively bring out the different active age groups' levels of uniqueness in Gauteng, South Africa. The pattern of 
internal migrants employed and unemployed shows that as age increases, the levels of the unemployed decreases while that of the employed increases.

Figure 3: Patterns of internal migrants employed and unemployed by Sex in Gauteng, 2011

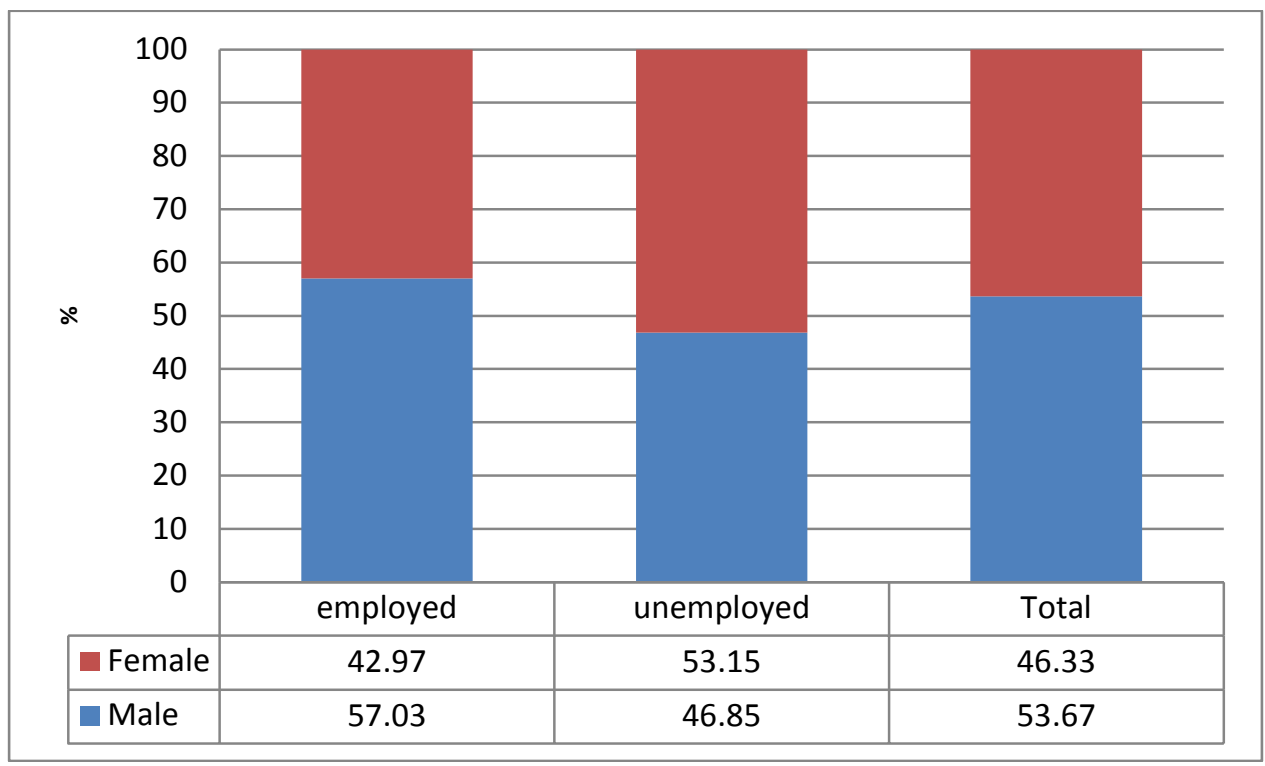

The table above indicates the percentage of males and females internal migrants employed and unemployed in Gauteng, 2011 by sex. It shows that a higher percentage of males are generally employed than females.

Figure 4: The participation of internal migrants in different industries by sex in Gauteng, 2011

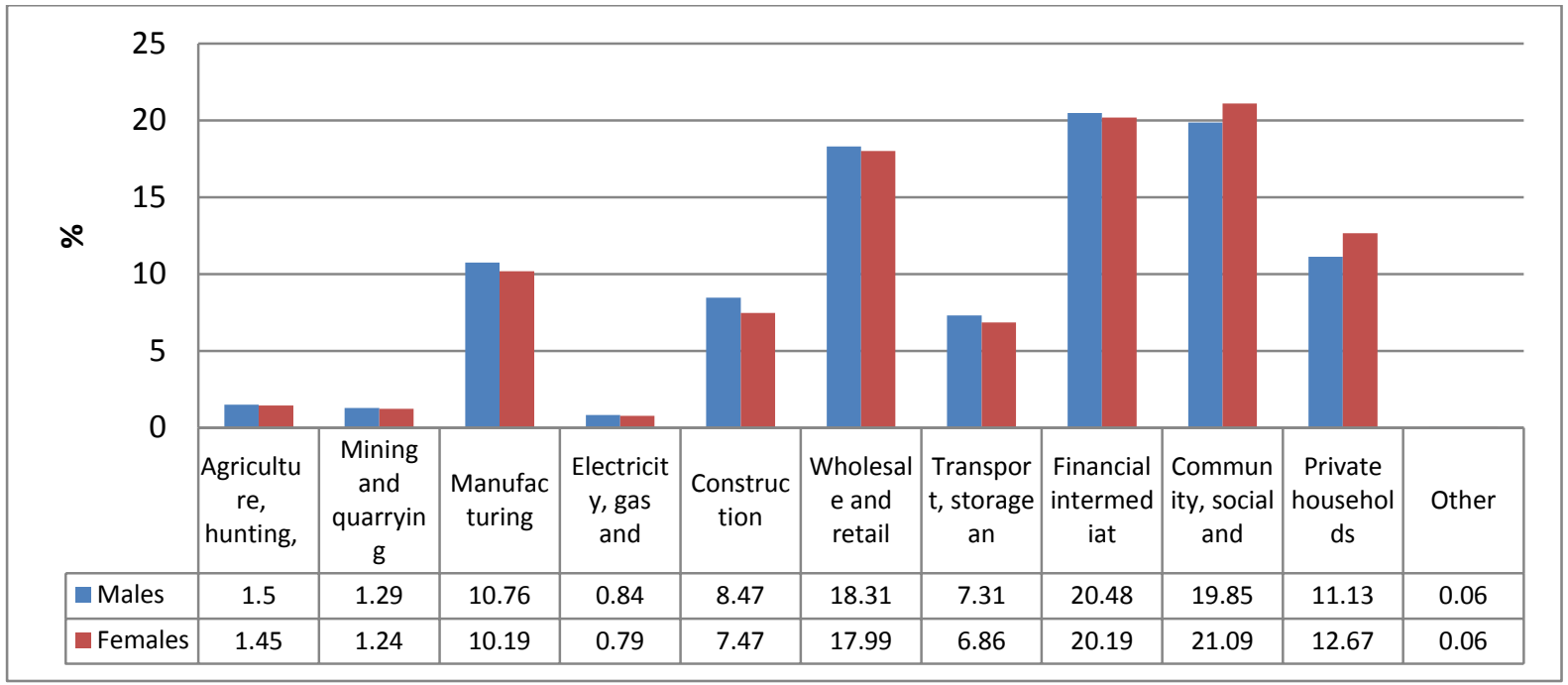

The figure above shows the labour participation rates per economic sector amongst the internal migrants. It shows that most migrants are employed in the financial intermediate, 
community and social services sectors. Also, the lowest participation rates are found in the agriculture, hunting, mining and quarrying industries (sectors) respectively.

Table 3: Distribution of internal migrants employed and unemployed by selected individual and socio-economic characteristics in Gauteng South Africa, 2011

Variable Unemployed Employed

\begin{tabular}{|lrr|}
\hline Population Group: & \\
\hline Black/African & 86.84 & 75.69 \\
\hline Indian/Asian & 2.02 & 3.23 \\
\hline Coloured & 3.59 & 3.34 \\
\hline White & 7.55 & 17.74
\end{tabular}

\section{Marital Status:}

\begin{tabular}{|lcc|}
\hline Married & 23.03 & 42.17 \\
\hline Living together & 10.84 & 13.74 \\
\hline Never married & 61.71 & 38.12 \\
\hline Widow/er & 2.28 & 2.32 \\
\hline Separated & 0.77 & 0.89 \\
\hline Divorced & 1.36 & 2.76 \\
\hline Income Level: & & \\
\hline No income & 80.88 & 8.71 \\
\hline R 1 - R 4800 & 4.61 & 3.14 \\
\hline R 4801 - R 9600 & 2.15 & 5.23 \\
\hline R 9601 - R 19200 & 6.44 & 13.70 \\
\hline R 19201 - R 38400 & 2.36 & 22.13 \\
\hline R 38401 - R 76800 & 1.41 & 17.53 \\
\hline R 76801 - R 153600 & 1.02 & 12.88 \\
\hline R 153601 - R 307200 & 0.73 & 9.50 \\
\hline R 307201 - R 614400 & 0.27 & 4.58 \\
\hline R 614401- R 1228800 & 0.07 & 1.72 \\
\hline R 1228801 - R 2457600 & 0.05 & 0.50 \\
\hline R2457601 or more & 0.02 & 0.36 \\
\hline Work for Salary: & & 90.04 \\
\hline Yes & 72.26 & 10.87 \\
\hline No & & \\
\hline School Attendance: & & \\
\hline Yes & & \\
\hline No & & \\
\hline Levels of Education: & & \\
\hline
\end{tabular}




\begin{tabular}{|lrc|}
\hline No schooling & 3.65 & 2.72 \\
\hline Some Primary school & 7.79 & 6.50 \\
\hline Completed Primary & 4.16 & 3.27 \\
\hline Some Secondary & 46.92 & 30.56 \\
\hline Grade 12/standard10 & 30.36 & 36.36 \\
\hline Higher & 6.82 & 20.06 \\
\hline Others & 0.31 & 0.53 \\
\hline Usual Residence: & & 92.27 \\
\hline Yes & 96.54 & 7.73 \\
\hline No & 3.46 & 67.03 \\
\hline Mother Alive: & 32.97 \\
\hline Yes & 69.50 & \\
\hline No & 30.50 & 44.08 \\
\hline Father Alive: & & 55.92 \\
\hline Yes & 49.97 & 97.50 \\
\hline No & 50.03 & 2.50 \\
\hline Geo-Type: & & \\
\hline Urban & 97.31 & \\
\hline Rural & 2.69 & \\
\hline
\end{tabular}

Table 3 above shows the distribution of employment and unemployment of internal migrants by selected individual and socio-economic characteristics in Gauteng, South Africa, 2011. The result shows that just above four fifth of the unemployed of migrants in Gauteng are the Black Africans, while the rest are from other population group. The Indian/Asians have the lowest levels of both unemployment and employment respectively.

The internal migrants who were never married contributed the highest to unemployment. The internal migrants who are married contributed the highest rate (42.2 percent) of the employed while the separated contributed the lowest percentage (0.89). The highest percentages of the employed were in the income range of R 19201 - R 38400, while less than ten percent worked for no income. About one in every 10 internal migrants employed do not work for salary in Gauteng and still attends school. The result also shows that the highest percentage (46.9 percent) of the unemployed migrants to Gauteng have some secondary education, followed by those with Grade 12/ Standard 10. Migrants with Grade 12 contributed the highest percentage of the employed, while those with other qualifications contributed the least. 
Respectively a high percentage of both internal migrants employed and unemployed are of usual residence in Gauteng. There are generally more people whose mothers are alive among the unemployed and a similar pattern is observed on the employed as well. The opposite is the case among those whose fathers are alive. The majority of the population, i.e. about nine in every ten employed and unemployed migrants in Gauteng reside in urban areas.

\subsection{Test of Association and Predictors of internal migrants being employed in Gauteng, South Africa 2011}

Table 4: Individual and socio-economic factors significantly associated with internal migrants being employed in Gauteng South Africa, 2011

\begin{tabular}{|l|l|l|l|l|}
\hline Variables & Test Level & $\begin{array}{l}\mathrm{P}>\mid \mathrm{z} / / \mathrm{Pr} \\
(\text { Outcome })\end{array}$ & $\begin{array}{l}\text { Sig. } \\
\text { Remark }\end{array}$ & $\begin{array}{l}\text { Study } \\
\text { Remark }\end{array}$ \\
\hline Age group & $\mathrm{P}<0.05$ & 0.000 & Sig & Associated \\
\hline Sex & $\mathrm{P}<0.05$ & 0.000 & Sig & Associated \\
\hline Population grp. & $\mathrm{P}<0.05$ & 0.000 & Sig. & Associated \\
\hline Marital status & $\mathrm{P}<0.05$ & 0.000 & Sig. & Associated \\
\hline Work for salary & $\mathrm{P}<0.05$ & 0.000 & Sig. & Associated \\
\hline Income Level & $\mathrm{P}<0.05$ & 0.000 & Sig. & Associated \\
\hline Levels of education. & $\mathrm{P}<0.05$ & 0.000 & Sig. & Associated \\
\hline School Attendance & $\mathrm{P}<0.05$ & 0.000 & Sig. & Associated \\
\hline Usual Residence & $\mathrm{P}<0.05$ & 0.000 & Sig. & Associated \\
\hline Mother alive & $\mathrm{P}<0.05$ & 0.000 & Sig. & Associated \\
\hline Father alive & $\mathrm{P}<0.05$ & 0.000 & Sig. & Associated \\
\hline Geo-type & $\mathrm{P}<0.05$ & 0.000 & Sig. & Associated \\
\hline
\end{tabular}

$\mathbf{P}<0.05=$ Statistically Significant at $5 \%$ level test (i.e. $P<0.05$ ): sig $=$ significant

Table 4 above shows individual and socio-economic factors significantly associated with internal migrants being employed in Gauteng South Africa, 2011. A chi-square analysis was conducted to test the association of migrants being employed in Gauteng by selected characteristics. The test was conducted at five percent level of significance (i.e. 95 percent confidence interval) and the results show that all tested characteristics were statistically significant ( $\mathrm{p}$-value=0.000) and thus, highly associated with internal migrants being employed in Gauteng. 
Table 5: Binary logistic regression showing odds ratios (OR) of the likelihood of selected individual and socio-economic characteristics predicting internal migrants being employed in Gauteng South Africa, 2011

\begin{tabular}{|c|c|c|c|c|c|}
\hline & Test 1 & Test 2 & Test 3 & Test 4 & Test 5 \\
\hline \multirow[t]{2}{*}{ Characteristics } & (Individual Model) & (Economic Model) & (Education Model) & (Contextual Model) & (General/Joint Model) \\
\hline & Odd Ratio (CI) & Odd Ratio (CI) & Odd Ratio CI & Odd Ratio CI & Odd Ratio CI \\
\hline \multicolumn{6}{|l|}{ Age Group: } \\
\hline $15-19$ & RC & & & & RC \\
\hline $20-24$ & $5.91(5.9-6.0)^{* *}$ & & & & $2.81(2.77-2.85) * *$ \\
\hline $25-29$ & $12.93(12.8-13.1)^{* *}$ & & & & $3.76(3.70-3.82) * *$ \\
\hline $30-34$ & $15.84(15.7-16.0)^{* *}$ & & & & $3.96(3.89-4.02)^{* *}$ \\
\hline $35-39$ & $17.36(17.2-17.5)^{* *}$ & & & & $4.10(4.03-4.17)^{* *}$ \\
\hline $40-44$ & $17.65(17.5-17.5)^{* *}$ & & & & $4.23(4.16-4.30) * *$ \\
\hline $45-49$ & $16.79(16.6-17.0)^{* *}$ & & & & $4.05(3.98-4.12)^{* *}$ \\
\hline $50-54$ & $14.18(14.0-14.3)^{* *}$ & & & & $3.45(3.39-3.51)^{* *}$ \\
\hline $55-59$ & $10.75(10.6-10.9)^{* *}$ & & & & $2.37(2.33-2.42) * *$ \\
\hline $60-64$ & $4.62(4.6-4.7)^{* *}$ & & & & $0.47(0.46-0.48)^{* *}$ \\
\hline \multicolumn{6}{|l|}{ Sex: } \\
\hline Male & RC & & & & RC \\
\hline Female & $0.58(0.5-0.6)^{* *}$ & & & & $0.73(0.72-0.73)^{* *}$ \\
\hline \multicolumn{6}{|c|}{ Population Group: } \\
\hline B/African & RC & & & & $\mathrm{RC}$ \\
\hline In/Asian & $1.10(1.0-1.1)^{* *}$ & & & & $0.88(0.86-0.89)^{* *}$ \\
\hline Coloured & $1.77(1.7-1.8)^{* *}$ & & & & $1.06(1.04-1.08)^{* *}$ \\
\hline
\end{tabular}




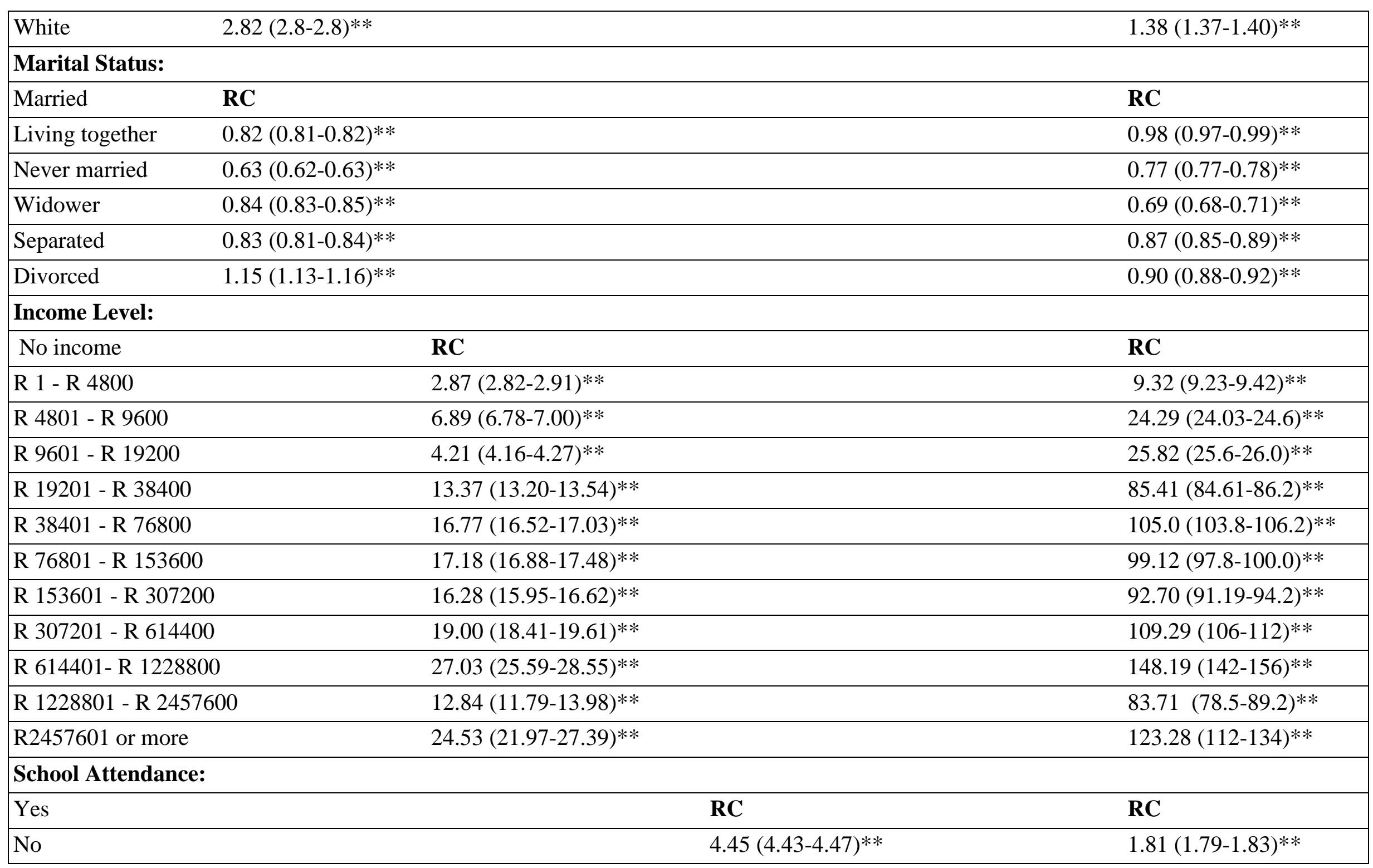




\begin{tabular}{|c|c|c|c|}
\hline \multicolumn{4}{|l|}{ Level of Education: } \\
\hline No schooling & RC & & RC \\
\hline Some Primary & $1.20(1.18-1.21)^{* *}$ & & $1.21(1.19-1.23)^{* *}$ \\
\hline Completed Primary & $1.22(1.20-1.23)^{* *}$ & & $1.29(1.27-1.32)^{* *}$ \\
\hline Some Secondary & $1.13(1.12-1.14)^{* *}$ & & $1.17(1.15-1.183)^{* *}$ \\
\hline Grade 12/standard10 & $1.99(1.97-2.00)^{* *}$ & & $1.40(1.38-1.43)^{* *}$ \\
\hline Higher & $6.02(5.96-6.09)^{* *}$ & & $1.85(182-1.88)^{* *}$ \\
\hline Others & $2.94(2.86-3.03)^{* *}$ & & $1.42(1.07-1.18)^{* *}$ \\
\hline \multicolumn{4}{|l|}{ Usual Residence: } \\
\hline Yes & & RC & RC \\
\hline No & & $2.39(2.38-2.41)^{* *}$ & $1.73(1.71-1.76)^{* *}$ \\
\hline \multicolumn{4}{|l|}{ Mother Alive: } \\
\hline Yes & & RC & RC \\
\hline No & & $1.02(1.02-1.03)^{* *}$ & $0.89(0.88-0.89)^{* *}$ \\
\hline \multicolumn{4}{|l|}{ Father Alive: } \\
\hline Yes & & RC & RC \\
\hline No & & $1.25(1.25-1.26)^{* *}$ & $0.95(0.95-0.96) * *$ \\
\hline \multicolumn{4}{|l|}{ Geo-Type: } \\
\hline Urban & & RC & RC \\
\hline Rural & & $1.00(0.99-1.01)$ & $1.15(1.13-1.16)^{* *}$ \\
\hline
\end{tabular}

Note: $^{* *}=$ Statistically Significant at $5 \%$ level test (i.e. $\left.\mathbf{P}<\mathbf{0 . 0 5}\right), \mathrm{CI}=$ Confidence interval, $\mathrm{RC}=$ Reference Category $=1$ 
The binary logistic regression in table 5 above shows the likelihood of selected individual and socio-economic characteristics predicting internal migrants being employed in Gauteng using odds ratios.

Test 1 looked at individual characteristics, test 2 at the economic model, test 3 at the education model, test 4 at the contextual model and test 5 at the general/joint model. The general/joint model factored in all the variables that were found to be statistically significant when tested using the chi-square at the bivariate level.

Overall, the results show that all the tested variables were statistically significant except for geo-type (i.e. rural-urban variable) at contextual model level compared to their reference category. Test 1 model controlled for all variables except age, sex, population group and marital status. Using age-group 15-19 as reference category, odds ratio levels of age indicate that as age increases the likelihood of employment in Gauteng up to age group 40-44 also increases, then it starts to decline consistently up to age group 60-64.

Test 1 shows that females are less likely to be employed than males, i.e. at an odds ratio of 0.58 (OR=0.58: $\mathrm{CI}=5.9-6.0)$. Using blacks as a reference category, whites have the highest odds of being employed in Gauteng, followed by coloureds. The odds ratio of the divorced migrants being employed is the highest in the marital status category. All other categories of the variable marital status have odds ratios of below 1.00 .

The economic model in test 2 factored in the odds ratio of income on the likelihood of being employed. Using no income as a reference category, the result shows that the likelihood of being employed increases as income increases in Gauteng. With odds ratio of 27.0 times (27.0: $\mathrm{CI}=25.59-28.55)$, the result shows that internal migrants with the annual income level R 614401- R 1228800 have the highest likelihood, while those at income level R 1 - R 4800 have the least likelihood at odds ratio 2.87 (OR=2.87: $\mathrm{CI}=2.82-2.9)$.

Test 3 model focussed on education characteristics and the likelihoods of being employed as an internal migrant in Gauteng when considering school attendance and the levels of education. At high odds ratio of 4.45 ( $\mathrm{OR}=4.45$ : $\mathrm{CI}=4.43-4.47)$, the likelihood of school attendance characteristics predicting a migrant being employed is high compared to those who are not attending school i.e., the reference categories. When using no schooling as a reference category, internal labour migrants with higher education have the highest odds of being employed while those with some secondary education have the least odds. 
Test 4 model focussed on the contextual model, which analysed variables measured at household levels. At odds ratio of 2.4 (OR=2.4: $\mathrm{CI}=2.38-2.41)$, those not of usual residence have a significantly higher odds of being employed as internal labour migrants compared to those who are of usual residence. The geo-type was not significant in the model but those whose father and mother were not alive have higher odds, 1.25, and 1.02 of being employed as internal migrants in Gauteng than those whose father or mother are still alive.

The general/ joint model was conducted as test 5 where all selected characteristics were jointly tested. The odds ratio of age shows the same pattern as in test 1 . It also shows that the likelihood of being employed is the highest at age group 40-44. The likelihood of females being employed as migrants in Gauteng increased from 0.58 in test 1 to 0.73 . Whites are still more likely to be employed than all other population groups while Indians were the only population group with the odds ratio of less than 1.00. When using the married as reference category, all the categories of variable marital status are below 1.00 indicating that the variable is a weak predictor of employment of internal migrants in Gauteng.

Also, at odds ratio of 148.2 (OR=148.2: $\mathrm{CI}=142-156)$, the result shows that internal migrants with annual income R 614401- R 1228800 have the highest likelihood compared to those with no income i.e. the reference category. The pattern observed with the economic characteristics at the general test is consistent with that of the economic model test among internal labour migrant in Gauteng.

With the odds ratios of $0.89(\mathrm{OR}=0.89$ : $\mathrm{CI}=0.88-0.89)$ and $0.95(\mathrm{OR}=0.95$ : $\mathrm{CI}=0.95-0.96)$ for mother alive and father alive the result shows that both variables are weak while other contextual characteristics, i.e. usual residence and geo-type are strong predictors at general/ joint test. 
Table 6: Binary logistic regression model predicting the likelihood of intervals of internal migrants being employed at their Province of previous residence (i.e. province of origin) compared to province of present residence (i.e. Gauteng)

\begin{tabular}{|c|c|c|c|c|c|c|c|c|c|c|c|c|}
\hline \multirow{3}{*}{$\frac{\text { Province }}{\text { Western Cape }}$} & \multicolumn{4}{|c|}{ 15-19 years in-migrants Gauteng } & \multicolumn{4}{|c|}{ 20-34 years in-migrants Gauteng } & \multicolumn{4}{|c|}{ 35-64 years in-migrants Gauteng } \\
\hline & \multirow{2}{*}{$\begin{array}{r}\begin{array}{l}\text { Odds } \\
\text { ratio }\end{array} \\
1.009 \\
\end{array}$} & \multirow{2}{*}{$\begin{array}{l}\mathbf{P}>\mathbf{z} \\
0.760 \\
\end{array}$} & \multicolumn{2}{|c|}{$\begin{array}{l}95 \% \text { confidence } \\
\text { interval }\end{array}$} & \multirow{2}{*}{$\begin{array}{r}\begin{array}{l}\text { Odds } \\
\text { ratio }\end{array} \\
0.666 \\
\end{array}$} & \multirow{2}{*}{$\begin{aligned} \mathbf{P}>\mathbf{z} \\
\\
0.000\end{aligned}$} & \multicolumn{2}{|c|}{$\begin{array}{l}95 \% \\
\text { confidence } \\
\text { interval }\end{array}$} & \multirow{2}{*}{$\begin{array}{l}\begin{array}{l}\text { Odds } \\
\text { ratio }\end{array} \\
0.648 \\
\end{array}$} & \multirow{2}{*}{$\begin{array}{l}\mathbf{P}>\mathbf{z} \\
0.000\end{array}$} & \multicolumn{2}{|c|}{$\begin{array}{l}95 \% \text { confidence } \\
\text { interval }\end{array}$} \\
\hline & & & 0.951 & 1.071 & & & 0.651 & 0.682 & & & 0.630 & 0.665 \\
\hline Eastern Cape & 1.094 & 0.001 & 1.036 & 1.155 & 0.661 & 0.000 & 0.646 & 0.677 & 0.621 & 0.000 & 0.605 & 0.638 \\
\hline Northern Cape & 0.905 & 0.007 & 0.842 & 0.973 & 0.664 & 0.000 & 0.648 & 0.680 & 0.649 & 0.000 & 0.632 & 0.667 \\
\hline Free State & 1.072 & 0.023 & 1.009 & 1.139 & 0.667 & 0.000 & 0.651 & 0.683 & 0.650 & 0.000 & 0.633 & 0.667 \\
\hline KwaZulu-Natal & 1.004 & 0.861 & 0.959 & 1.052 & 0.652 & 0.000 & 0.637 & 0.667 & 0.593 & 0.000 & 0.578 & 0.608 \\
\hline North West & 1.142 & 0.000 & 1.079 & 1.209 & 0.661 & 0.000 & 0.646 & 0.677 & 0.632 & 0.000 & 0.616 & 0.649 \\
\hline Mpumalanga & 1.201 & 0.000 & 1.137 & 1.271 & 0.663 & 0.000 & 0.648 & 0.680 & 0.636 & 0.000 & 0.620 & 0.653 \\
\hline Limpopo & 1.133 & 0.000 & 1.082 & 1.187 & 0.649 & 0.000 & 0.634 & 0.664 & 0.560 & 0.000 & 0.547 & 0.575 \\
\hline
\end{tabular}

* Statistically significant at $95 \%$ confidence interval

Table 6 above shows the result of binary logistic regression model predicting the likelihood of internal migrants being employed at their Province of previous residence (i.e. province of origin) compared to province of present residence (i.e. Gauteng) by functional age groups. For the migrants aged 15-19 years, the odds ratios (OR) of Western Cape and KwaZulu-Natal are not statistically significant. The internal migrants from all provinces except Northern Cape have odds ratios of above 1.00, which indicate that they are more likely to be employed in their provinces of origin than as migrants in Gauteng. The odds ratio of less than 1.00 for Northern Cape implies that migrants are more likely to be employed in Gauteng. 
The second functional age group was internal migrants aged 20-34. All the provinces were found to be statistically significant with lower odds ratios compared to the reference category i.e. being employed in Gauteng. The migrants from Free State have the highest likelihood of being employed in their province of origin with odds ratio of 0.667 compared to other provinces where migrants originate. The migrants from Limpopo had the least likelihood of being employed in Limpopo than in Gauteng compared to all provinces followed by KwaZulu-Natal.

In the age group 35-64, all the provinces are statistically significant (P-value $=0.000$ ) and also have lower odds ratios compared to the reference category. Migrants from Limpopo and KwaZulu-Natal still have the lowest odds ratios of being employed in their provinces of origin compared to all other provinces respectively. The migrants from Free State and Northern Cape have the highest likelihood of being employed in their provinces of origin respectively compared to other provinces.

The confidence interval shows the range of occurrence of likelihood. Western Cape migrants in the functional age of 15-19 have a confidence interval of 0.951 and 1.071which means that their likelihood of being employed in the province of origin ranges between these two limits, the lower and the upper limits. The odds ratio of 1.009 can be anywhere between the lower limits 0.951 and upper limits 1.071 . The value of 1.009 is an estimated value. The same goes for all other odds ratios, they fall between the upper and the lower limit of confidence interval. 
4.3. Spatial settlements of internal migrants employed and unemployed by Main Place in Gauteng, South Africa 2011

Figure 5: spatial settlement of employed internal migrants in Gauteng by Main Place, 2011

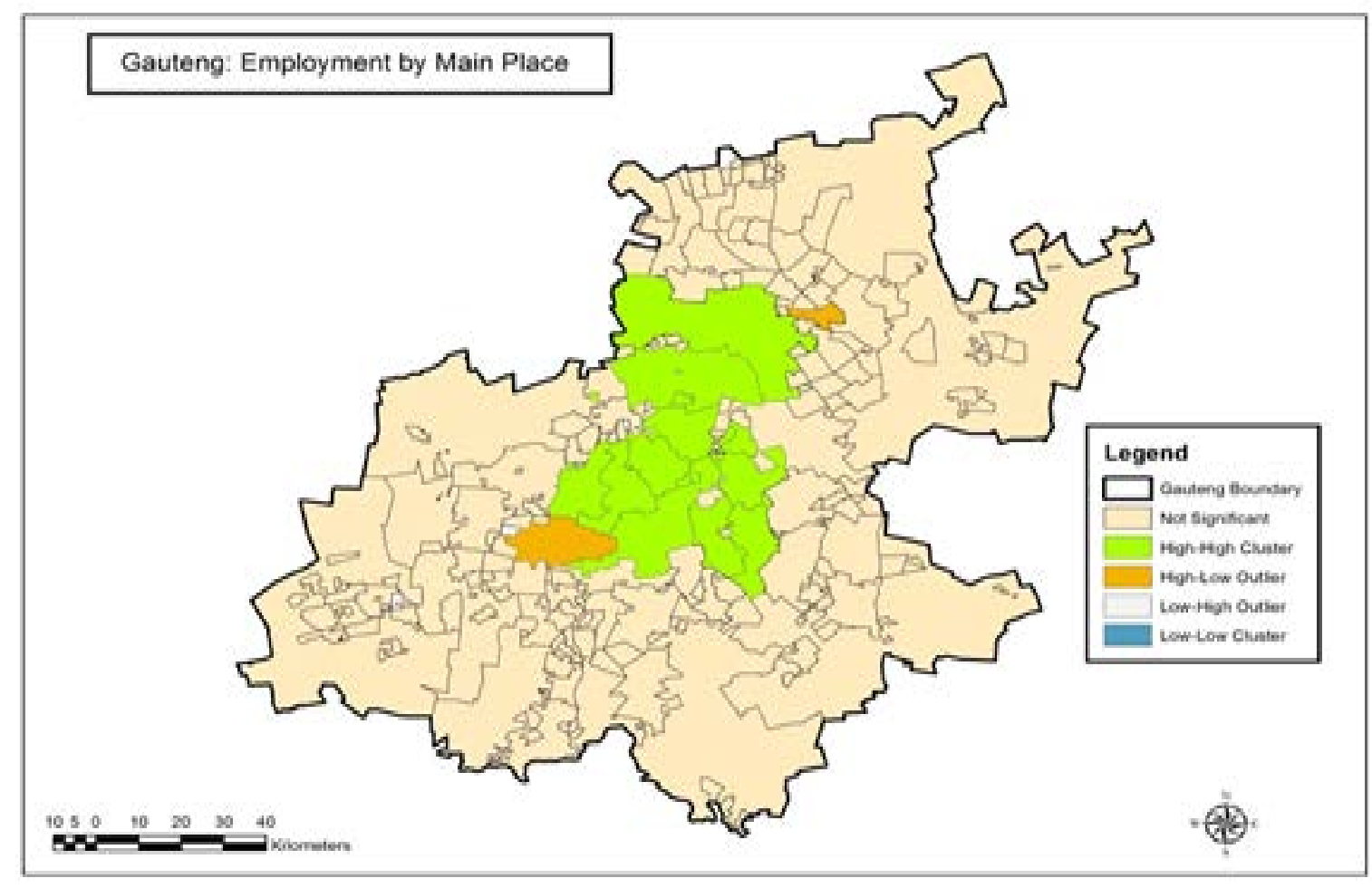

The figure above was constructed using Anselin Morans I. It shows the clustering and dispersal of migrants in Gauteng at 5 percent level of significance. It shows a high-high cluster of migrants in the area between Johannesburg and Pretoria. A large area is not significant which shows that migrants settle closer to employment centres that the two towns and surrounding areas offer. The high-low outliers are observed mainly around Soweto area which is surrounded by area of high employment on one end and the area that is not significant on the other end. 
Figure 6: Spatial settlement of the unemployed internal migrants in Gauteng by Main Place, 2011

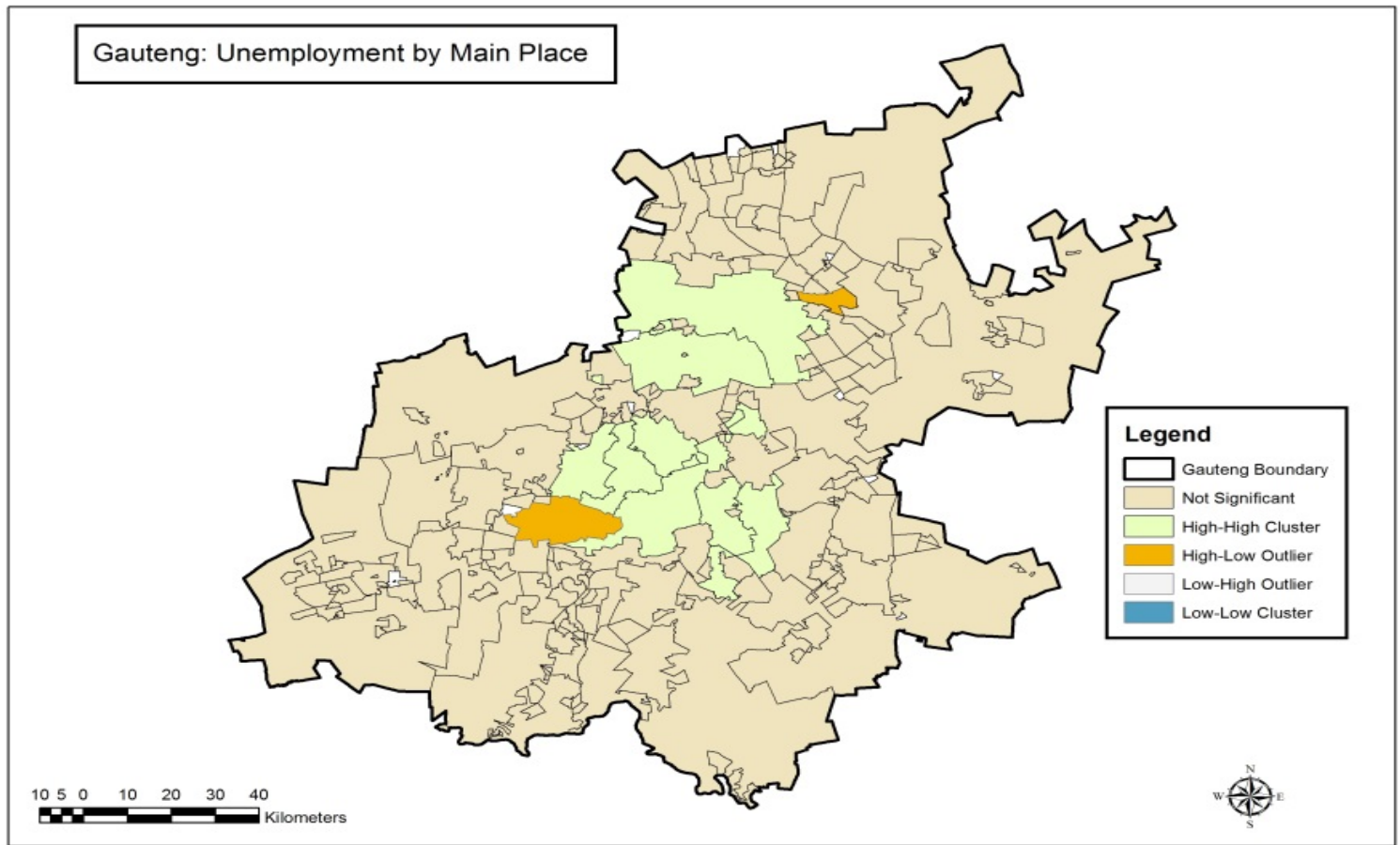

The figure above indicates the settlement areas of the unemployed migrants in Gauteng at 5 percent level of significance. The area of high-high cluster is also mainly in the centres of Johannesburg and Pretoria. It also shows the same pattern as the settlement of the employed. The area between the two cities has some insignificant centres which could explain low levels of settlement for the unemployed in the area of Midrand but high levels of settlement in the areas of Tembisa in Ekurhuleni. The areas around Soweto show high-low outlier.

Figure 7: Settlement by metro: employed migrants in Ekurhuleni, 2011

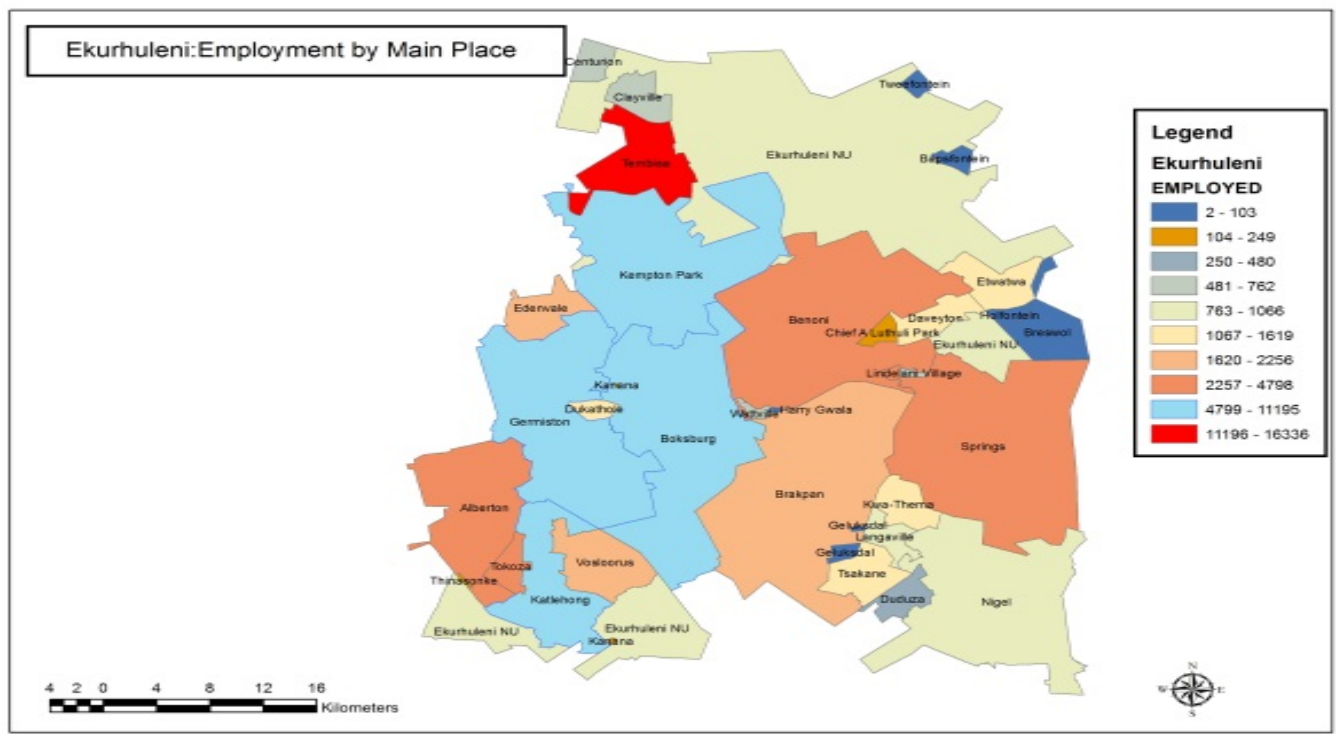


Figure 8: Settlement by metro: unemployed migrants in Ekurhuleni, 2011

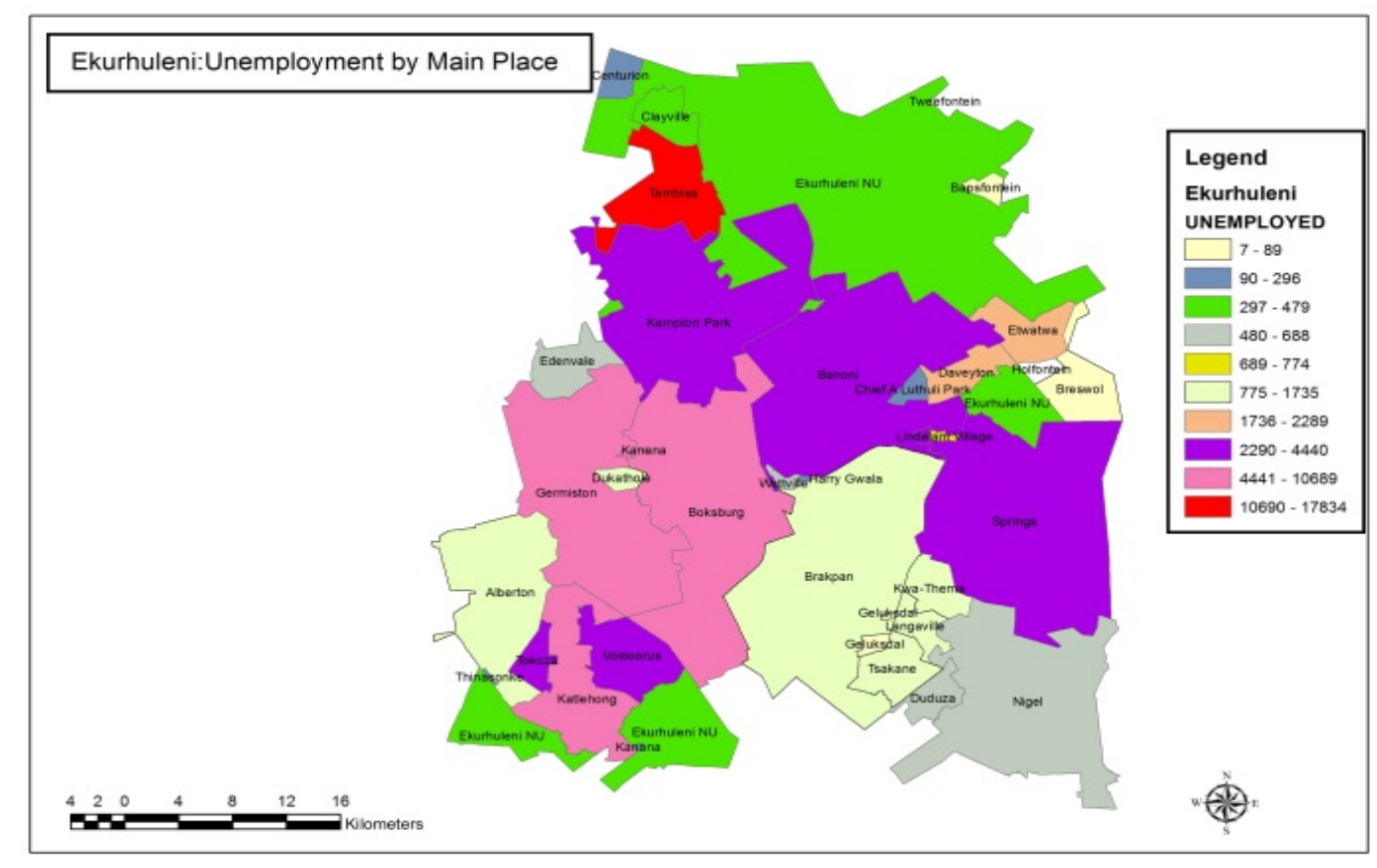

The figures 7 and 8 above indicate the settlement of internal migrants in Ekurhuleni metro by main place. The highest numbers of both the employed and unemployed migrants stay in Tembisa. There is also a clustering of the employed in areas of Kempton Park, Kanana, Germiston, Boksburg and Katlehong. The trend is the same with the unemployed except in Kempton Park which seems to be more attractive to the employed. Small area at the border of the metro like Bapsfontein and Breswol are least attractive to both the employed and the unemployed migrants. 
Figure 9: Settlement by metro: employed migrants in the city of Johannesburg, 2011

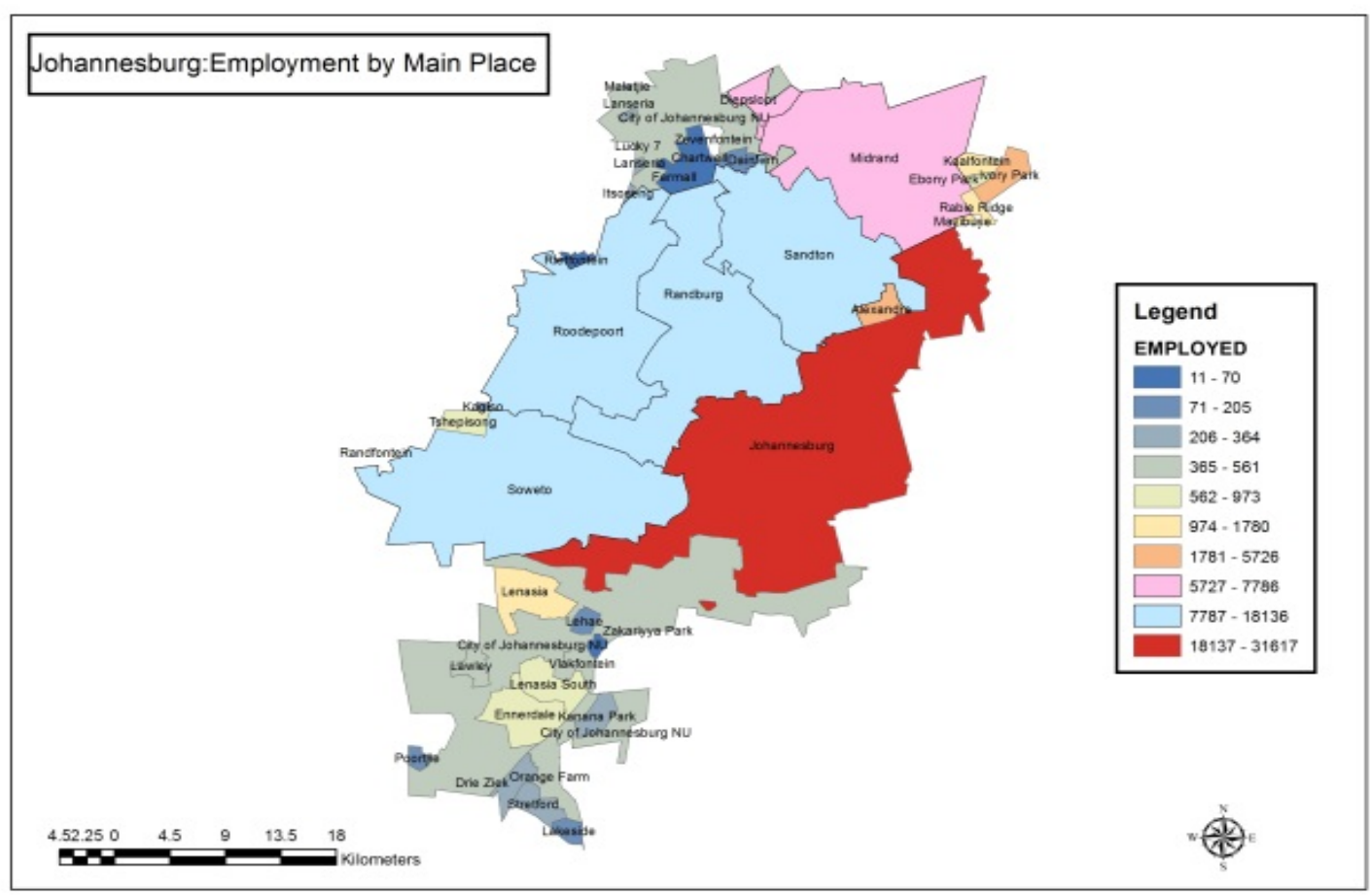

Figure 10: Settlement by metro: unemployed in the city of Johannesburg, 2011

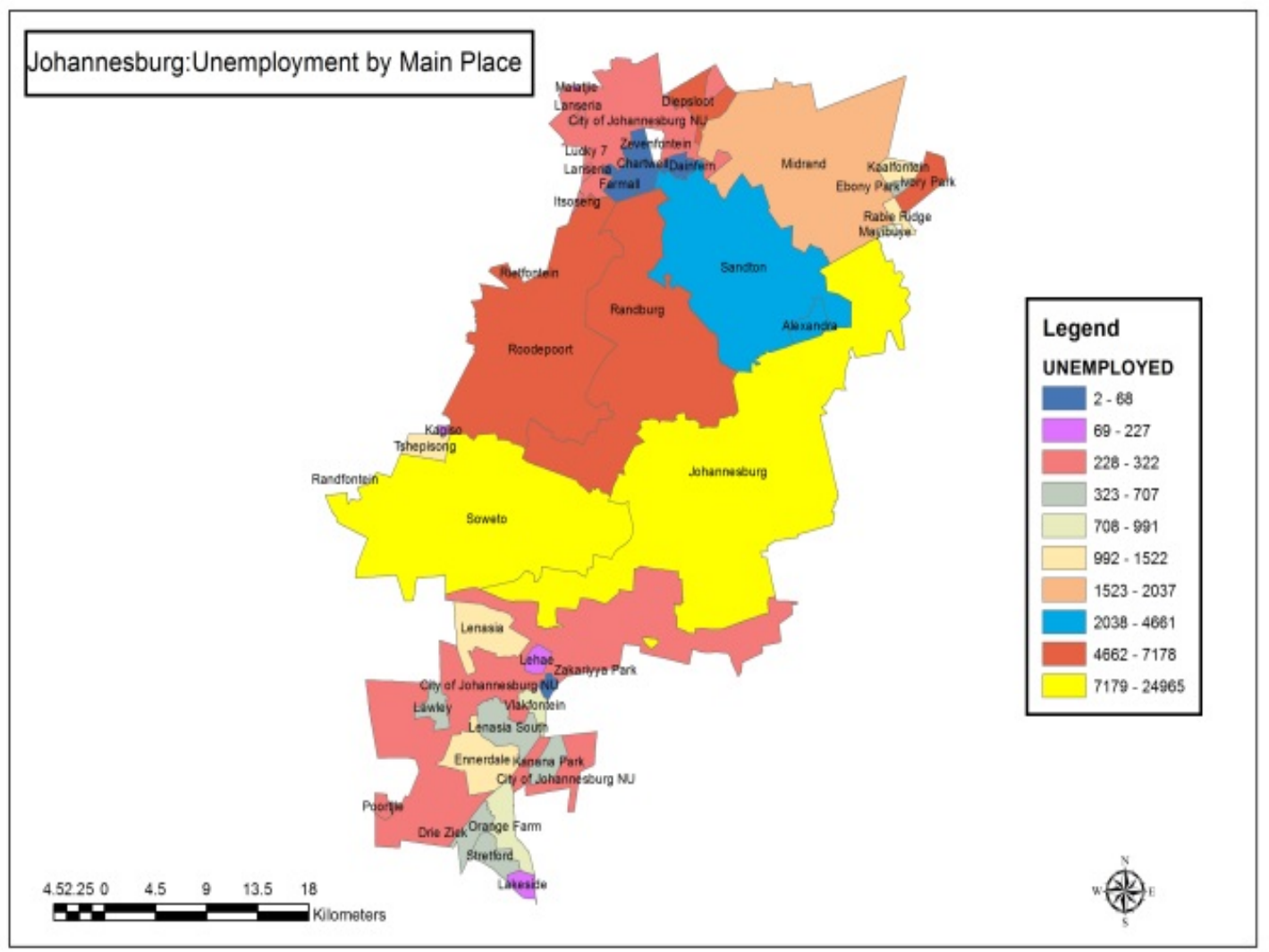

The figures 9 and 10 above indicate the spatial settlement of the employed and unemployed in the city of Johannesburg. The highest concentration of the employed migrants is in 
Johannesburg, followed by areas of Sandton, Randburg, Roodepoort and Soweto. The unemployed are highly concentrated in the areas of Johannesburg and Soweto followed by areas of Randburg and Roodepoort. Surprisingly the settlement of the unemployed in Alexandra seems to be the same as Sandton which could be attributed to the mushrooming of informal settlements.

Figure 11: Spatial settlement by metro: employed migrants in City of Tshwane, 2011

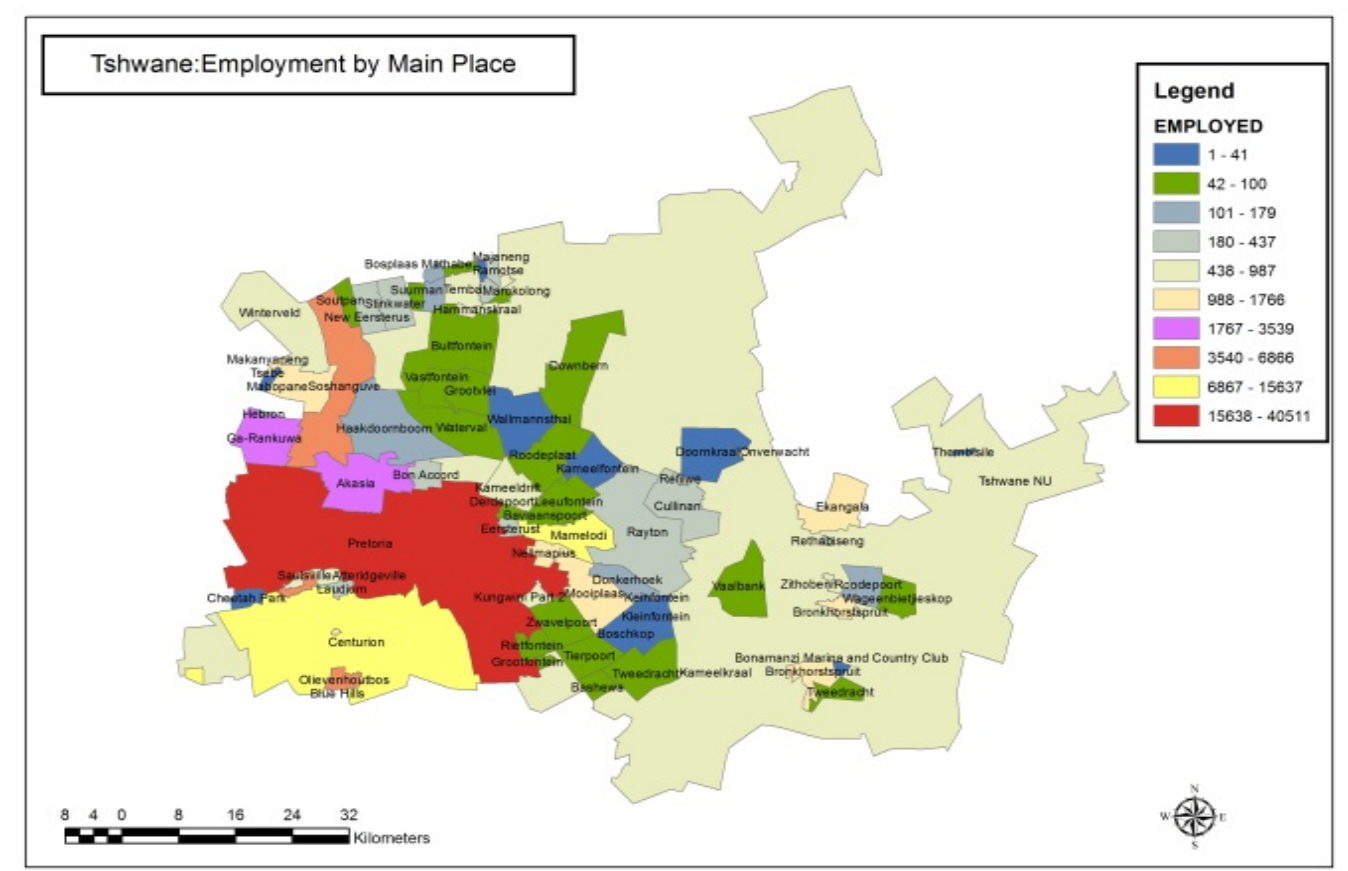

Figure 12: Spatial settlement by metro: unemployed migrants in City of Tshwane, 2011

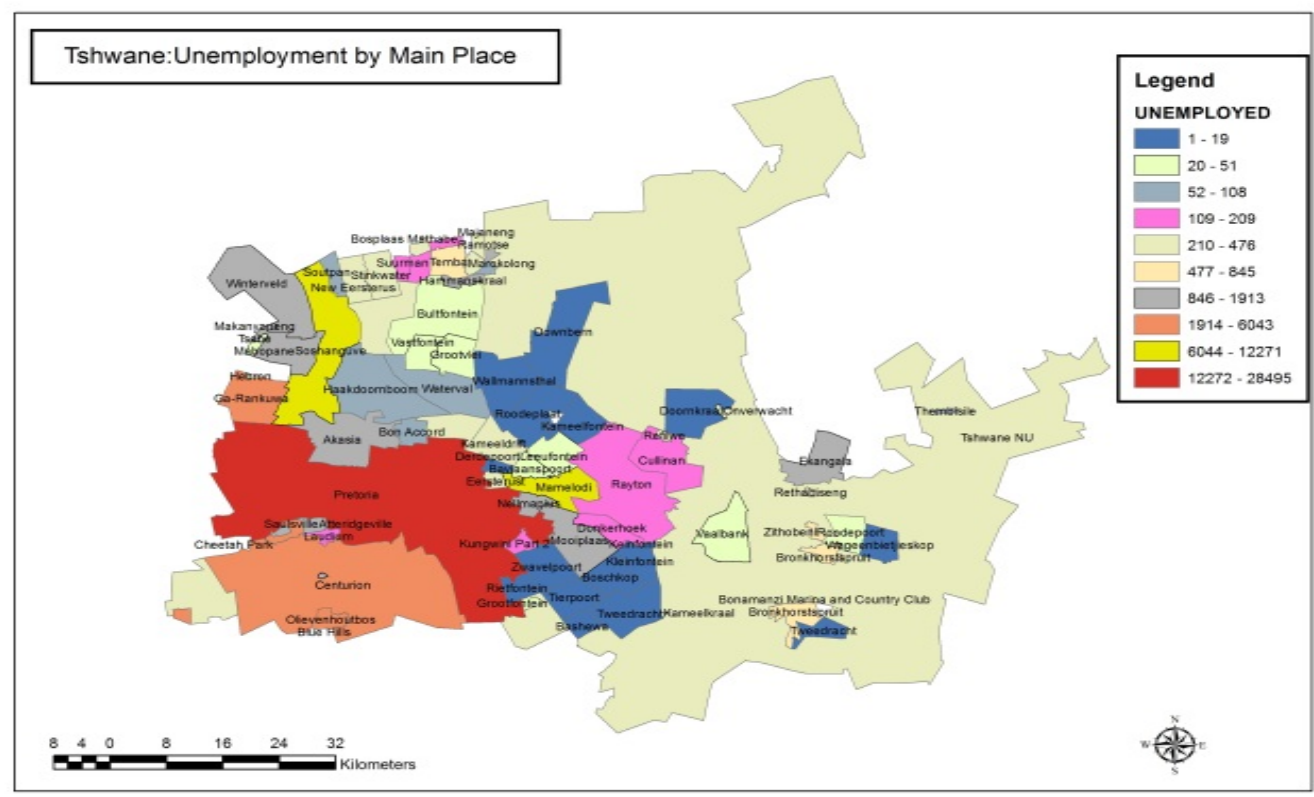


The figures 11 and 12 above indicate the spatial settlement of the employed and unemployed in the city of Tshwane, Gauteng. Both the employed and unemployed are mostly concentrated in the area of Pretoria town, followed by areas of Mamelodi and Centurion. The corridor from Soutpan pass Soshanguve to Pretoria is also attractive for the employed which could be attributed to high numbers of firms in areas like Rosslyn. The settlement of the unemployed also follows the same pattern. The same corridor from Soutpan right to Pretoria CBD and Mamelodi are the second most populated areas for unemployed migrants, followed by Centurion and Garankuwa. The areas of Walmansdal and Kameelsdrift have the least number of both employed and unemployed migrants. 


\section{CHAPTER 5}

\section{DISCUSSIONS, CONCLUSIONS AND RECOMMENDATION}

\subsection{Discussions}

The general objective of the study is to critically examine the levels, individual and socioeconomic characteristics associated with internal migrants labour force participation and their spatial settlement pattern in Gauteng, in 2011. The result of levels of migrants and nonmigrants shows that there are more unemployed migrants than non-migrants in Gauteng and most of them are female in the functional age category 15-19. The economic participation rates per sector amongst the internal labour migrants shows that most migrants are employed in the financial, community and social services sector. Also, the pattern of internal migrants employed and unemployed shows that as age increases, the levels of the unemployed decreases while that of the employed increases. As was expected the lowest participation rate was found in the agriculture, hunting, mining and quarrying sectors respectively.

The variables considered for test in the study were informed by earlier literatures in the area of study and their availability in the dataset used. At the multivariate level, characteristics tested were those found to be significant and thus, association with employment of migrants at the bivariate test level using chi-square test. Overall, the result showed that at the bivariate level of analysis, all tested characteristics were found to be statistically significant and thus, associated with the employment of internal migrants in Gauteng. At multivariate level, with the exception of geo-type (rural-urban) characteristics, all further tested characteristics were found to be statistically significant and thus, good predictors of internal migrants' labour being employed in Gauteng.

Specifically, the test 1 model shows that age, sex, population group and marital status are associated and statistically significant and thus, good predictors of internal migrants being either employed or unemployed in Gauteng. The odds ratio of being employed increases consistently up to age group 40-44 years and then, starts declining as age increases, compared to the reference category 15-19 years. The pattern is consistent with the findings made by Fauvelle-Aymar (2013), although with a significantly greater difference. The study found that the median age of internal migrants was 32 years. This pattern was also found to be consistent at the general model test level (i.e., Test 5 model). Also, the pattern is quite in 
context because as one gets older, the chance of being employed gets slimmer as employers, if possible, tend to employ younger rather than older people.

The age which internal migrants were more likely to be employed in 2011 confirms the theory of long term investment of labour migrants. According to the theory, more young people tend to migrate because they can potentially benefit for a longer period (Bauer and Zimmerman, 1999; Lucas, 1997). The finding from the study shows that the unemployment rate is the highest in age group 15-19.

Although weak, the results show that the likelihood of females being employed in Gauteng at the individual characteristics test (test 1 ) is 0.58 times. This increased to 0.73 times in the general test model (test 5 model) compared to the reference category. This increase could have a number of implications. Firstly, it complements the findings by Posel (2003) that female labour migration in South Africa has been on the rise since 1993, probably as a result of loosening internal structures of control in the families. It could also be attributed to South African laws promoting female emancipation since the post-apartheid era.

According to studies, level of income plays a major role in attracting migrants to an area. Similarly, the study shows that the odd ratio of income is very high, thus indicating that income levels play a major role in attracting migrants to Gauteng. Also, the binary logistic regression model on test 2 indicates that as the level of income increases, the odds ratio of being employed as internal migrant increases. The findings also indicate that migrants have a better chance of being employed in Gauteng than in any other province in South Africa. The odds ratio of being employed in the province of origin is above 1.00 only for migrants aged 15-19 for all provinces except Northern Cape, although with a low level of significance. On the other hand, the age groups 20-34 years and 35-64 years have high levels of significance and lower odds ratios compared to their reference categories.

The percentage of employed migrants without income in 2011 was 8.71. The logic of working without income can be attributed to under employment which contributes to relative or absolute deprivation and political instability as postulated in new economics theory of migration. According to Fischlowitz and Engel (1969) the conditions of migrants do not change as they move from rural to urban areas. This proves to be the case for those without income even though they indicated that they were employed. Migration can be the outcome of increasing income for employed migrants from low to high income categories (Fischlowitz and Engel, 1969). 
Test 3 looked at the odds ratio of being employed by levels of education. The higher education levels create potential for higher possibilities of employment. According to Ghatak (2003) unemployment in urban areas is projected to be between 15 and 20 percent but amongst internal labour migrants in Gauteng it was above 40 percent. The high unemployment rate could be attributed to an increase in the number of unskilled migrants because findings from the study show that those with Grade 12 and higher have higher odds of being employed compared to all other education levels categories, when using no schooling as a reference category.

The level of education is well correlated with employment rate (Lucas, 1997). The findings show that the highest percentage of the unemployed is those with some secondary education (46.92 percent). The highest percentage of the employed is the migrants with Grade 12 and higher. This finding is consistent with theory as postulated by Lucas (1997) that those with higher levels of education are likely to be more migrants as they have a better chance of being employed in the area of destination.

The likelihood of migrants being employed in their respective provinces of origin in South Africa compared to Gauteng is mainly above 1.00 for functional age group 15-19 and below 1.00 for functional age groups 20-34 and 35-64. This implies that those aged 15-19 had a better chance of being employed in their respective provinces of origin while those aged 2034 and 35-60 had a better chance of being employed in Gauteng than any other province in South Africa. This could apply to the majority in the latter two age groups because they are not studying any longer as tests 3 and 5 indicate that those who are not studying any longer have a higher likelihood of being employed compared to those who are still studying. It could also be the outcome of urban development bias which Ajaero and Onokala (2013) referred to in an earlier study. According to the authors, it ensured overconcentration of wealth assets, purchasing power and economic activities while other areas were neglected.

According to Todaro and Smith (2006) migration is driven by the desire to improve economic status through employment. The findings show that there's a high likelihood of being employed in Gauteng than any other province in South Africa for those aged 20-34 and 35-64 years. Also, this outcome is consistent with the macro perspective of neoclassical theory of differentiation in labour supply and demand and also provides substantiation for the need for diversification as postulated by new economics of migration theory. 
The argument can also be that Gauteng in South Africa is providing pull factors more than any other province. It is widely indicated in different sources that, compared to the destination, poverty and a lack of economic opportunities in the area of origin are the strongest push factors. Migration as a means to access resources in South Africa will therefore always be predominantly to Gauteng. Test 4 variables were also significant and could also help shed light on the push factors. When these factors are controlled in test 1 model, the odds ratio of female employment was 0.58 while in the general model (test 5 ) is 0.78. This means females whose parents are not alive are likely to be employed more than those whose parents are still alive. However, the odds of being employed for variables father alive and mother alive are above 1.00 in test 4 and less than 1.00 in test 5 . The geo-type is not significant in test 4, which means that, being either from rural or urban areas does not affect the chances of being employed in Gauteng, but in test 5 those from rural areas have 1.15 odds of being employed from the urban areas as reference group.

The spatial settlement can help planners anticipate future settlement planning of both the employed and unemployed internal migrants. It could also explain the mushrooming of informal settlements closer to the employment centres. Todaro (1980) argued that migrants have two options, either to accept a job in the informal sector or remain unemployed while searching for a formal sector job. And on this view, the World Bank (2006) indicated that they will choose the former. The informal economy has to service the formal sector employees as clients hence the study shows that there is not much difference in settlement patterns at the main place level in Gauteng, South Africa. The picture could be different if analysis is done at enumeration area level as the lowest level of data collection.

\subsection{Conclusion and Recommendation}

Gauteng will continue to experience high levels of economic migration because it presents the highest likelihood of employment than all other provinces. The odds ratio of earning income is also higher. This supports the neo-classical view that migration is driven mainly by the need for better employment and income opportunities. The findings have also shown that with the exception of rural-urban characteristics, which were not statistically significant at contextual model level, all other tested individual and socio-economic characteristics have an association and thus, good predictors of employment of internal migrants in Gauteng. The maps of spatial settlement distribution of employed and unemployed internal migrants in Gauteng show very little variation in settlement patterns. 
The study therefore concludes by recommending that all factors found to be statistically significant in the study be considered in policy formation by the government and other concerned stakeholders in their policy formations concerning internal economic migrants in Gauteng. Also, the study further concludes by recommending that planners always provide low cost settlement plans closer to where the employed are staying as it could mean that it is closer to the economic opportunities.

\subsection{Recommendation for Further Studies}

The theory of migration focusses on many aspects. It will be interesting if the further studies could analyse the impact of social contacts on migration or the impact of networking on migration generally in Gauteng South Africa. 


\section{REFERENCES}

Ackah, C. \& Medvedev, D. (2010): Internal Migration in Ghana: Determinants and Welfare Impacts. Policy Research Working Paper 5273

Adams, Jr, R.H. (1993): The economic and Demographic determinants of International Migration in Rural Egypt. The Journal of Development Studies, 30(1), pp 146-167.

Ajaero, C.K. \& Onokala, P.C. (2013): The Effects of Rural-Urban Migration on Rural Communities of South-eastern Nigeria. University of Nigeria, Nigeria.

Arango, J. (2000): Explaining migration: a critical view. International Social Science. Journal 52 (165): 283-296.

Bauer, T.K. \& Zimmermann K.F. (1999): Assessment of Possible Migration Pressure and its Labour Market Impact Following EU Enlargement to Central and Eastern Europe: I ZA Research Report No. 3.

Black, M. (1983): Migration of young Labor Force Entrants. Socio-Economic Planning Sciences 17: pp 267-280.

Budlender, D (2014): Migration and employment in South Africa: Statistical analysis of the migration module in the Quarterly Labour Force Survey, third quarter 2012. MiWORC Report N5, Johannesburg: African Centre for Migration \& Society, University of the Witwatersrand.

Clark, D.E., Herrin, W., Knaap, T and White, N. (2003): Migration and Implicit Amenity Markets: Does Incomplete Compensation Matter? Journal of Economic Geography 3289 307.

Cross, C. (2009): Migration Trends and Human Settlements: Some Implications for Service Centres. Human Sciences Research Council.

De Haas, H., (2007): Migration and Development: A Theoretical Perspective. Bielefeld: COMCAD, Working Papers - Centre on Migration, Citizenship and Development, 29.

Development Policy Research Unit, (2005): Internal Migration to the Gauteng Province. DPRU Policy Brief 04/P3. University of Cape Town.

Fauvelle-Aymar, C. (2014): Migration and employment in South Africa: An econometric analysis of domestic and international migrants (QLFS (Q3) 2012). MiWORC Report

$\mathrm{N}^{\circ}$ 6. Johannesburg: African Centre for Migration \& Society, University of the Witwatersrand.

Fischlowitz, E. \& Engel, M.H. (1969): Internal Migration in Brazil. The International Migration Review, 3(3), pp 36-46.

George J. B., Stephen G. B. \& Stephen J. T. (1992): Assimilation and the Earnings of Young Internal Migrants. The Review of Economics and Statistics, 74 (1), pp 170-175. 
Ghatak, S. (2003): Introduction to Development Economics: 4th edition. USA \& Canada, Routledge.

Government Communication and Information System (GCIS), (2013) South Africa's Yearbook 2012/2013. Pretoria. GCIS.

Green, D. \& Kadoya, H. (2015): Contact and Threat: Factors Affecting Views on Increasing Immigration in Japan. Politics and Policy, 43 (1), pp 59-93.

Guriev, S. \& Vakulenko, E. (2013): Internal Migration and Interregional Convergence in Russia. Social Science Research Network Working Paper Series, 2200539.

Kekez, V. (2015): Clustering of Immigration Population in Helsinki Metropolitan Area, Finland: A Comparative Study of Exploratory Spatial Data Analysis Methods. University of Helsinki.

Kok, P., Gelderblom, D., Oucha J.O. \& Van Zyl, J (eds), (2006): Migration in South and Southern Africa: Dynamics and Determinants. Tokai, HSRC Press.

Kok, P., O’Donovan, M., Bouare, O and Van Zyl, J. (2003): Post-apartheid Patterns of Internal Migration in South Africa. HSRC Publishers, Cape Town.

Kurekova, L. (2011). Theories of migration: Conceptual Review and Empirical Testing in the Context of the EU East-West flows. Paper prepared for Interdisciplinary conference on Migration. Economic Change, Social Challenge. April 6-9, 2011, University College London.

Lee, E.S., (1966): A Theory of Migration. Demography, 3(1): 47-57.

Lewis, W.A. (1954): Economic Development with Unlimited Supplies of Labour. Manchester School, 22 (2), pp 139-191.

Lucas, R. E.B. (1997): Internal Migration in Developing Countries. Boston University.

Massey, D.S., et el. (1993): Theories of international migration: A review and appraisal. Population and Development Review 19 (3):431-466.

Massey, D.S., et el (1994): An Evaluation of International Migration Theory: The North American Case. Population and Development Review, 20(4), pp 699-751.

Mberu, B.U. (2006). Internal migration and household living conditions in Ethiopia. Demographic Research 14(21), 509-540.

Morrison, P.S \& Clark W.A. (2011): Internal Migration and Employment: Macro Flows and Micro Motives. Environment and Planning-Part A 43(8).

Odimegwu, Frade, De Wet \& Adedini, (2016): Demography of Labour Force in a Transitional Society. New York, Routledge

Oosthuizen, M and Naidoo, P (2004): Internal Migration to the Gauteng Province. University of Cape Town. Development Policy Research Unit. ISBN 1-920055-03-7.

Piore, M. J. (1979): Birds of Passage. Migrant Labor and Industrial Societies. Cambridge University Press. 
Posel, D. (2003): Have Migration Patterns in post-Apartheid South Africa Changed? South Africa University of Natal.

Rempel, H. (1981): Rural-urban labour migration and urban unemployment in Kenya. Laxenburg, Austria: International Institute for Applied Systems Analysis

Richarme, M. (2002): Eleven Multivariate Analysis Techniques: Key Tools in Your Marketing Research Survival Kit. USA. Arlington.

SACN. (2006): South African State of the cities report, 2006. Johannesburg: South African Cities Network

SACN. (2016): State of South African Cities Report, 2016: The People’s Guide. SACN: Johannesburg. ISBN 978-0-620-71464-8

Sahota, G.S.(1968): An Economic Analysis of Internal Migration in Brazil. Journal of Political Economy, 76 (2), pp. 218-245

Shimeles, A. (2010): Migration Patterns, Trends and Policy Issues in Africa. Working Papers Series N 119, African Development Bank, Tunis, Tunisia.

South Africa. ( 2015): Fifteen Year Progress Review of the Implementation of the Population Policy for South Africa (1998) and the International Conference on Population and Development (ICPD) Programme of Action (1994). Department of Social Development.

South Africa (2012): National Development Plan: Vision 2030. Pretoria. The Presidency

South Africa. (2009): National Urban Development Framework: Harnessing a common vision for Growth and Development of South Africa's Towns, Cities and City-Regions. Pretoria: Department of Cooperative Governance and Traditional Affairs and the Presidency in Partnership with the South African Cities Network

South Africa, (2007): National Spatial Development Perspective 2006. The Presidency: South Africa.

Standing, G. (1981): Migration and Modes of Exploitation: Social Origins of Immobility and Mobility. Journal of Peasant Studies 8, pp 173-211.

Stark, O. (1991): The Migration of Labor. Cambridge: Basil Blackwell.

Statistics South Africa (2005): Achieving a better life for all: Progress between Census '96 and Census 2001 / (Report No. 03-02-16 (2001). Pretoria.

Statistics South Africa (2012): Census 2011 release - P0301.4. Pretoria:

Statistics South Africa (2015): QLFS Trends 2008-2014. Pretoria, Statistics South Africa

Todaro, (1980): Internal Migration in Developing Countries: A Survey: University of Chicago Press pp361-402)

Todaro, M.P. (1969): A Model of Labor Migration and Urban Unemployment in Less Developed Countries. The American Economic Review, 59(1): 138-148

Todaro, M. P. \& Smith, S. (2006): Economic Development. Boston: Addison Wesley. 
Todes, A., et el (2010): Contemporary South African Urbanisation Dynamics. Urban Forum 21(1), 331-348.

United Nations Development Programme (UNDP), (1994): Human Development Report. New York: Oxford University Press2

WALKER, C. (1990): Gender and the Development of the Migrant Labour System 18501930: An Overview. In Women and Gender in Southern Africa to 1945, ed by Cherryl Walker. pp. (168-196). Cape Town: David Philip Publishers.

World Bank, (2006): Global Economic Prospects: Economic Implications of Remittances and Migration. Washington, World Bank.

Zuberi, T. and Sibanda, A., (2004): How Do Migrants Fare in a Post-Apartheid South African Labor Market? The International Migration Review 38 (4): 1462-1491

Zwiech, P. (2008): Why are Women Discriminated Against on the Labour Market in Poland? The Results of the Questionnaire Survey. Economics \& Sociology, 1(1). 